\title{
RAPID RECONNAISSANCE OF GEOTHERMAL PROSPECTS USING SHALLOW TEMPERATURE SURVEYS.
}

by

Leonard A. LeSchack, John E. Lewis, David C. Chang, Robert I. Lewellen and Norbert W. O'Hara

Second Technical Report

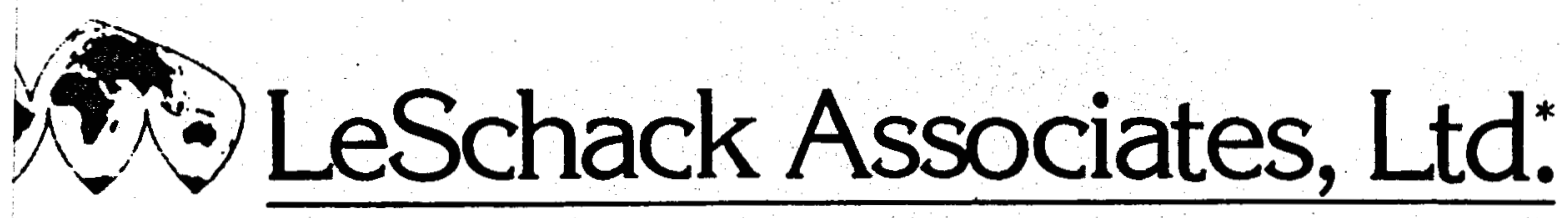

Suite 116

1111 University Blvd. W.

Silver Spring.

Maryland 20902, U.S.A.

(301) 649.1670

P.O. Box 88

San Ramon.

California 94583. U.S.A.

(415) 837.0101

Prepared for the United States

DEPARTMENT OF ENERGY

Under Contract EG-77-C-01-4021

and

OFFICE OF NAVAL RESEARCH

Under Contract No0014-78-C-0535

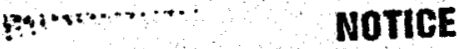

PORTIONS OF THIS REPORT ARE ILLEGIBLE.

It has been reproduced from the best available copy to permit the hroadest possible availability.

March 1979

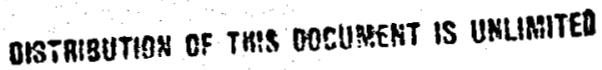

* formerly Development and Resources Transportation Co. 


\section{DISCLAIMER}

This report was prepared as an account of work sponsored by an agency of the United States Government. Neither the United States Government nor any agency Thereof, nor any of their employees, makes any warranty, express or implied, or assumes any legal liability or responsibility for the accuracy, completeness, or usefulness of any information, apparatus, product, or process disclosed, or represents that its use would not infringe privately owned rights. Reference herein to any specific commercial product, process, or service by trade name, trademark, manufacturer, or otherwise does not necessarily constitute or imply its endorsement, recommendation, or favoring by the United States Government or any agency thereof. The views and opinions of authors expressed herein do not necessarily state or reflect those of the United States Government or any agency thereof. 


\section{DISCLAIMER}

Portions of this document may be illegible in electronic image products. Images are produced from the best available original document. 


\section{ABSTRACT}

Discussed here is a continuation of work begun two years ago under this contract. Our conclusions strengthen those drawn in the earlier work.

In our previous work, thermistor probes were used to collect shallow $(2 \mathrm{~m})$ soil-temperature data at 27 sites at Long Valley, California, and 102 sites at the Coso (KGRA), California. These geothermal areas are locations where traditional deep reconnaissance geothermal-survey bore holes had earlier been emplaced, allowing direct comparison of our shallow temperature results with standard geothermal exploration techniques. The comparisons were favorable.

We concluded that exploration decisions based on the deep reconnaissance holes could also have been based on the more cost-effective $2-\mathrm{m}$ measurements. This is due to relatively small variations in elevation, surface roughness and albedo and soil thermal diffusivities at these sites, coupled with a strong thermal anomaly, conditions not always found at other potential prospects. We investigated the magnitude and variation of these effects at Coso. Using data bases developed earlier, we made quarterly readings at the 102 sites so a complete annual temperature cycle at $2 \mathrm{~m}$ could be determined. Additional temperature measurements were made at Long Valley.

We constructed an annual temperature model designed to simulate temperatures at $2 \mathrm{~m}$ based on inputs of surface weather conditions for an 18-month period, soil thermal diffusivity, and surface roughness and albedo. The thermal diffusivity was computed using the phase $\mathrm{lag}$ at $2 \mathrm{~m}$ derived from the four seasonal measurements. Surface roughness and albedo were measured when the probes were inserted. The model appeared to closely simulate 2-m temperatures for the non-anomalous sites at Coso, making it possible to rapidly compute corrections to shallow temperature measurements at other areas.

We also investigated the application of a simple thermal conductivity probe to rapidly compute the near-surface thermal diffusivity at Long Valley. Our computed values compared favorably with those obtained independently using the phase lag method at the four probe sites at Long Valley. Such rapid measurements would be required for making corrections in an operational survey.

Using a preliminary model and analysis of the Coso data, we proved the importance of measuring soil thermal diffusivity data at each temperature probe site. We examined Olmsted's (1977) 1-m temperature data at Upsal 
Hogback, Nevada, and suggested corrections for soil thermal diffusivity. When applied, Olmsted's shallow temperature measurements more nearly targeted an anomaly found at $30 \mathrm{~m}$ than did his uncorrected data.

We compared our corrected 2-m temperature anomaly at Coso with a low altitude aeromagnetic anomaly and an anomaly outlined by electrical resistivity methods, both obtained by the University of Utah; they coincide. We identified two intersecting faults at Coso by the sharp contrasts of thermal diffusivity, probably due to a brecciated zone. The faults were congruent with a resistivity anomaly of the same shape and location Identified by the University of Utah and are consistent with their interpretations of the anomaly.

Finally, we have reviewed the ground water conditions at our various sites and conclude that making shallow temperature measurements where there is a modest amount of ground water flow needn't be a hopeless task. It often complicates interpretation, but does not necessarily invalidate application of the technique.

In summary, this work has provided an analytical method for making necessary corrections to $2-\mathrm{m}$ soil temperature data: This opens the way for use of shallow temperature surveys as a rapid and inexpensive reconnaissance tool for geothermal exploration at a variety of locations. 
1. Introduction and Background

2. Sensitivity Tests of a Preliminary Annual

Temperature Model

3. Seasonal Variations of the 2-m Temperatures at Coso

4. Correcting 1-m Temperature Data at Upsal Hogback for Thermal Diffusivity Variations: An example of the Importance for Making Corrections Where the Temperature Anomaly is Small

5. Comparison of Our 2-m Temperature Data at Coso with Other Geological and Geophysical Data

6. An Outline of a Complete Shallow Temperature Survey

7. Preliminary Tests with a Thermal Conductivity Probe

8. Effects of Ground Water on Shallow Temperature Measurements: A Review of the Long Valley Area

8.1 Location and Geology of Long Valley

8.2 Ground Water and 1ts Effects on Shallow Temperature Surveying

9. Summary and Conclusions

10. Acknowledgement 40

11. References $\quad$ - $\quad 41$

Appendix A: Map Contouring by SYMAP : 43

Appendix B: Long Valley Temperature Measurements, August 1978

\section{DISCLAIMER}

This report was prepared as an account of work sponsored by an agency of the United States Government. Neither the United States Government nor any ageney thereof, nor any of their employees, makes any warranty, express or implied, or assumes any legal liability or responsibility for the accuracy, completeness, or usefulness of any information, apparatus, product, or process disclosed, or represents that its use would not infringe privately owned rights. Reference herein to any specific commercial product, process, or service by trade name, trademark, manufacturer, or otherwise does not necessarily constitute or imply its endorsement, recommendation, or favoring by the United States Government or any agency thereof. The views and opinions of authors expressed herein do not necessarily state or reflect those of the United States Government or any agency thereof. 


\section{Introduction and Background}

Shallow ( $2 \mathrm{~m})$ soil temperature data have been collected at 27 sites at Long Valley, California, and at 102 sites at Coso, California (LeSchack, et al, 1977). These are locations where traditional deep reconnaissance geothermal survey bore holes have been emplaced, allowing us to compare directly our shallow temperature results with standard exploration techniques. We considered the effects of surface roughnesss, albedo, soil thermal diffusivity, topography and elevation in making the necessary corrections to our 2-m temperature data. The corrected data for both locations had been plotted by computer to avoid personal bias, and were compared with the published 10-m contour data at Long Valley and the 30-m contour data for Coso. Close geometrical similarity was observed and we identified previously located faults.

Four thermistor probes were left at representative sites at Long Valley; 102 probes were left at Coso so that additional measurements could be made over the year following the original emplacement. Observations were made at all sites as follows:

Coso

22-24 September 1977

2-4 February 1978

18-20 May 1978

4-6 August 1978
Long Yalley

10 July 1977

16 May 1978

9-11 August 1978

These new data have been used to verify previous findings as well as to compare with temperatures computed with an annual temperature model designed for future survey work. The model was used to establish the nature and range of corrections necessary to apply to shallow temperature survey readings.

\section{Sensitivity Tests of a Preliminary Annual Temperature Model}

An annual model that predicts temperature variations at $2-m$ depth has been designed to provide numerical corrections to our observed 2-m temperature measurements. It is being tested against data recorded at the Coso KGRA. The model consists of a solar radiation generator which supplies the basic energy input, and an algorithm which takes into account the surface albedo, surface roughness and thermal diffusivity to a depth of $2 \mathrm{~m}$. Surface weather data from the Naval Weapons Center, China Lake, California (the closest weather station to our Coso area) have been used to specify the regional synoptic conditions. The details of the model will be discussed in a forthcoming report, but it is important to note some preliminary results at this time. 
At Coso, variation of surface albedo from 25-40\% had little noticeable effect on 2-m temperatures. Variation of surface roughness (Lettau, 1969) from 3-20 cm caused a variation at $2-\mathrm{m}$ depth of about $2{ }^{\circ} \mathrm{C}$. Variation of thermal diffusivity from $0.0014-0.8023 \mathrm{~cm}^{2} / \mathrm{sec}$ resulted in temperature differences between $2^{\circ}$ and $3^{\circ} \mathrm{C}$ at $2-\mathrm{m}$. Since this was the general range of surface variables found at Coso, it is clear that at least the surface roughness and thermal diffusivity should be accounted for when evaluating 2-m temperature data at this area. As noted earlier (LeSchack et al 1977), the surface variables at Coso appeared to vary little relative to other potential survey areas (i.e., in more humid regions). Examination of 2-m temperature contour maps of Coso recorded in September, 1977, February, 1978, May, 1978, and August, 1978, shows that for the normal temperature areas this variation is significant. Because the $2-\mathrm{m}$ temperature anomaly at Coso is so strong $\left(10^{\circ} \mathrm{C}\right.$ above the normal values) the variations due to surface roughness and thermal diffusivity are somewhat overshadowed. However, this is not likely to be the case at many other areas where shallow temperature surveying might be used as an operational tool. It is largely for these other areas that the annual temperature model is being developed. The need for such a model is shown dramatically at the Upsal Hogback area in Nevada where the temperature anomaly is only $3^{\circ} \mathrm{C}$ and measurement of thermal diffusivity is vital (see section 4 of this report).

Work is continuing on the model. We will refine it for use at a variety of potential geothermal prospects where obtaining a meaningful 2-m temperature anomaly will depend on whether or not the proper corrections generated by the model have been applied to the raw data.

\section{Seasonal Variations of the 2-m Temperatures at Coso}

Though a clear temperature anomaly appeared when our September, 1977, 2-m data were corrected and plotted (LeSchack, et $a l, 1977$ ), and this anomaly coincided well with the electrical resistivity and aeromagnetic anomalies independently obtained by Fox (1978a and 1978b), respectively, we determined it would be valuable to observe seasonal temperature variations at Coso. Figures 1-4 show the contours* of temperatures at $2 \mathrm{~m}$, corrected for elevation, for September, 1977, February, 1978, May, 1978, and August, 1978, respectively.

At first glance examination of these contour maps shows only minor temperature pattern differences.

*Contour maps prepared by SYMAP program. See Appendix A. 

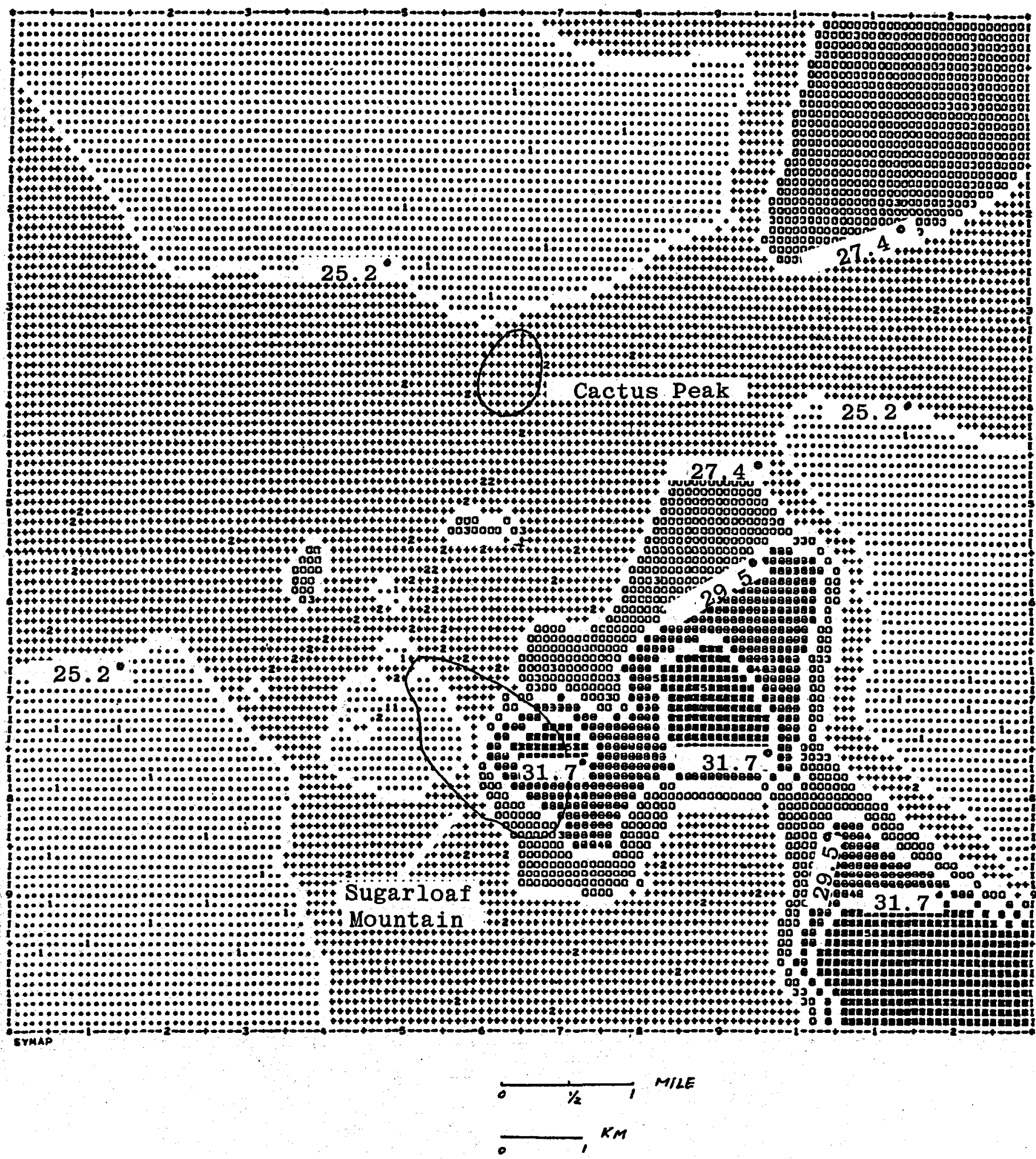

FIGURE 1; 2-m temperature contour map for Coso, September 1977, corrected for elevation. Temperature in ${ }^{\circ}$. 

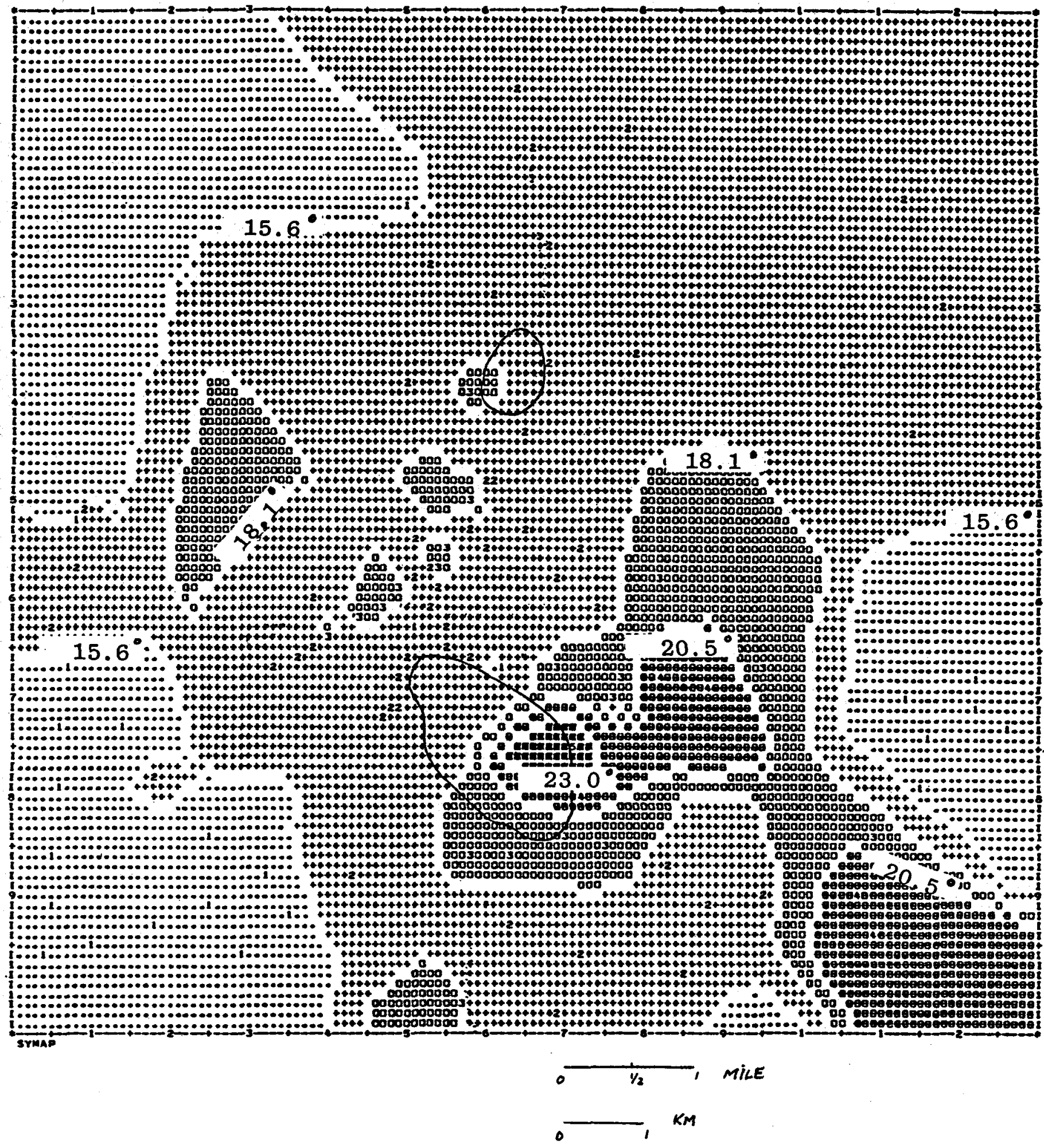

FIGURE 2: 2-m temperature contour map for Coso, February 1978, corrected for elevation, Temperature in ${ }^{\circ} \mathrm{C}$. 

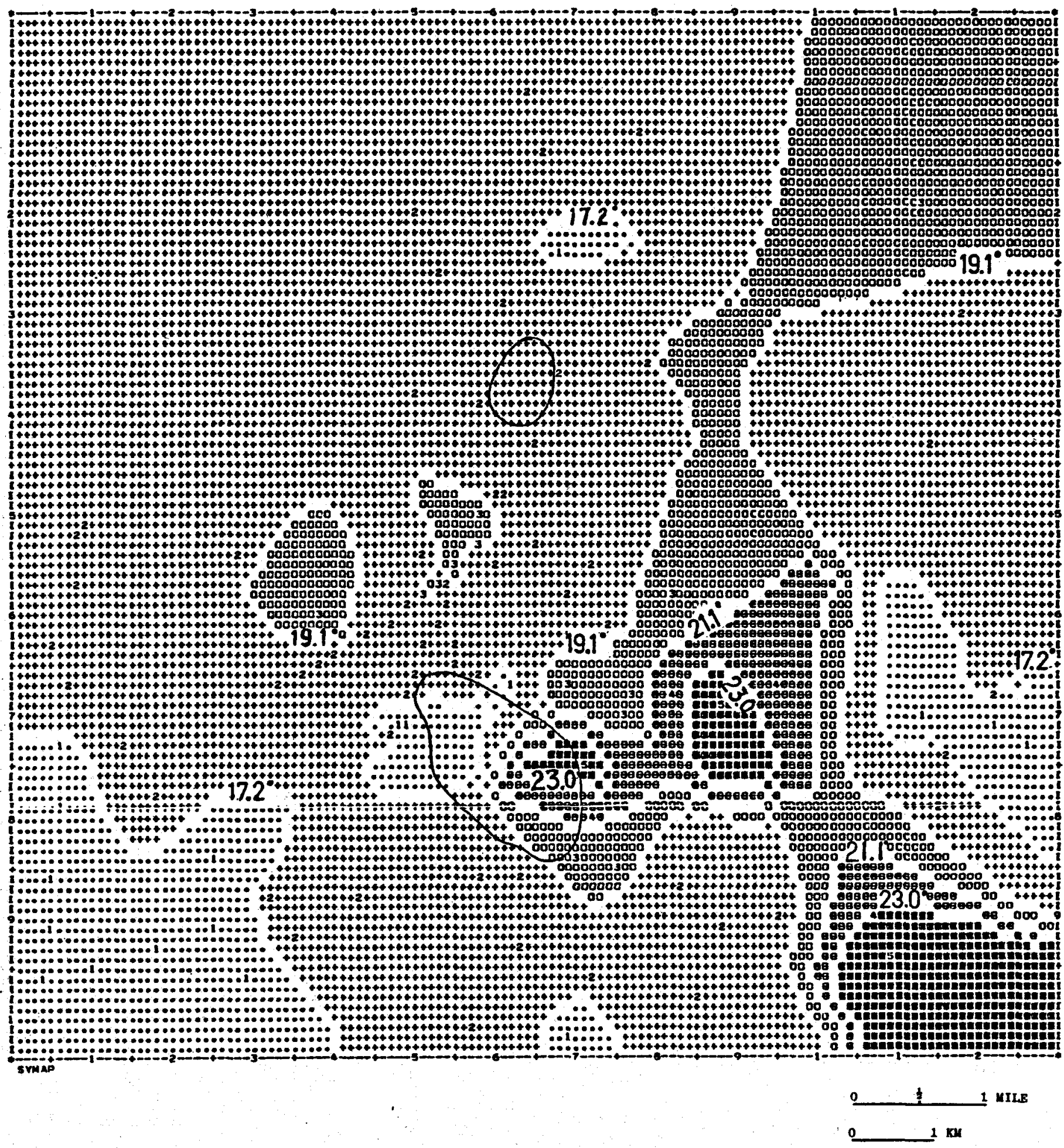

FIGURE 3: 2-m temperature contour map for Coso; May 1978, corrected for elevation. Temperature in ${ }^{\circ} \mathrm{C}$. 

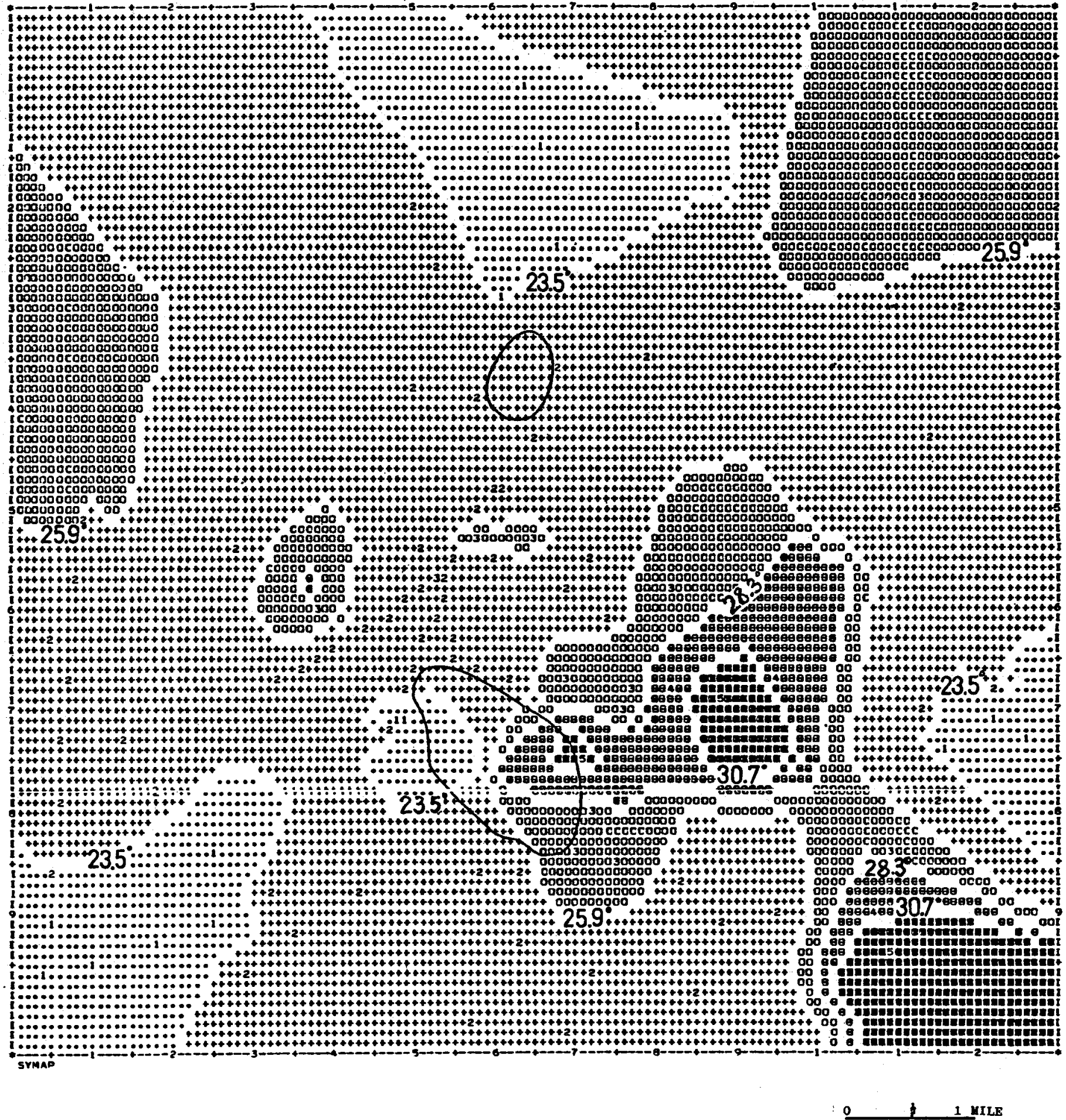

0

1 KM

FIGURE 4: 2-m temperature contour map for Coso, August 1978, corrected for elevation. Temperature in ${ }^{\circ} \mathrm{C}$. 
Overall temperatures vary with the season, but the anomaly pattern remains much the same, A decision to proceed with further exploration would undoubtedly have been made based on any one of the contour maps independently.

It is important to investigate the cause of these temperature pattern differences over time. The differences do not significantly alter the shape of the temperature anomaly at Coso owing to the high signal-to-nolse ratio at this prospect. This would not be the case with a weaker anomaly elsewhere. From the sensitivity tests conducted with our preliminary annual temperature model, it is clear that variations in soll thermal diffusivity play the most significant role in affecting temperature variation at $2-m$ depth. We have computed a value of thermal diffusivity at each of the 102 sites at Coso using the phase lag method.

From data collected in September, 1977, and February, May and August, 1978 (Table 1), we plotted an annual temperature curve at $2-\mathrm{m}$ depth. We assumed at $2 \mathrm{~m}$ the curve would be sinusoldal (following the procedures outlined in Van Wijk, 1966) and therefore fitted a sine curve to the data points. The annual low at the surface was assumed to be 21 December. From the curves constructed for each site, the time lag in weeks between the low at the surface and the low at $2 \mathrm{~m}$ was computed. A value of thermal diffusivity integrated between the surface and $2 \mathrm{~m}$, and integrated over time was calculated using the following relationship:

$$
t_{x}-t_{0}=\frac{x}{2} \sqrt{\frac{p}{\pi \alpha x}}
$$

where

$$
\begin{aligned}
& x \text { is the thickness of layer } x(\mathrm{~cm}) \\
& \alpha_{x} \text { is the thermal diffusivity of layer } x \\
& \left(\mathrm{~cm}^{2} \mathrm{~s}^{-1}\right) \\
& P \text { is the period of the temperature wave(s) }
\end{aligned}
$$

and

$$
\begin{gathered}
t_{x}-t_{0} \text { is the time lag between the temperature } \\
\text { waves at the land surface and at the } \\
\text { base of layer } x(s) .
\end{gathered}
$$

In evaluating (1) we took to to be 21 December, the time of the minimum solar energy input to the surface. The time, $t_{x}$, when the solar minimum migrated down to the depth, $x=$ $200 \mathrm{~cm}$, was estimated from the sine curves fitted to the temperatures recorded at each site and shown in Table 1. Lag times, $t_{0}-t_{x}$, are due to the thermal diffusivity and varied from 10-15 weeks. The period, $P$, is that of the 
TABLE 1: Corrected Temperatures, Mean Temperatures, $\Delta T$ 's and Thermal Diffusivities for Coso KGRA

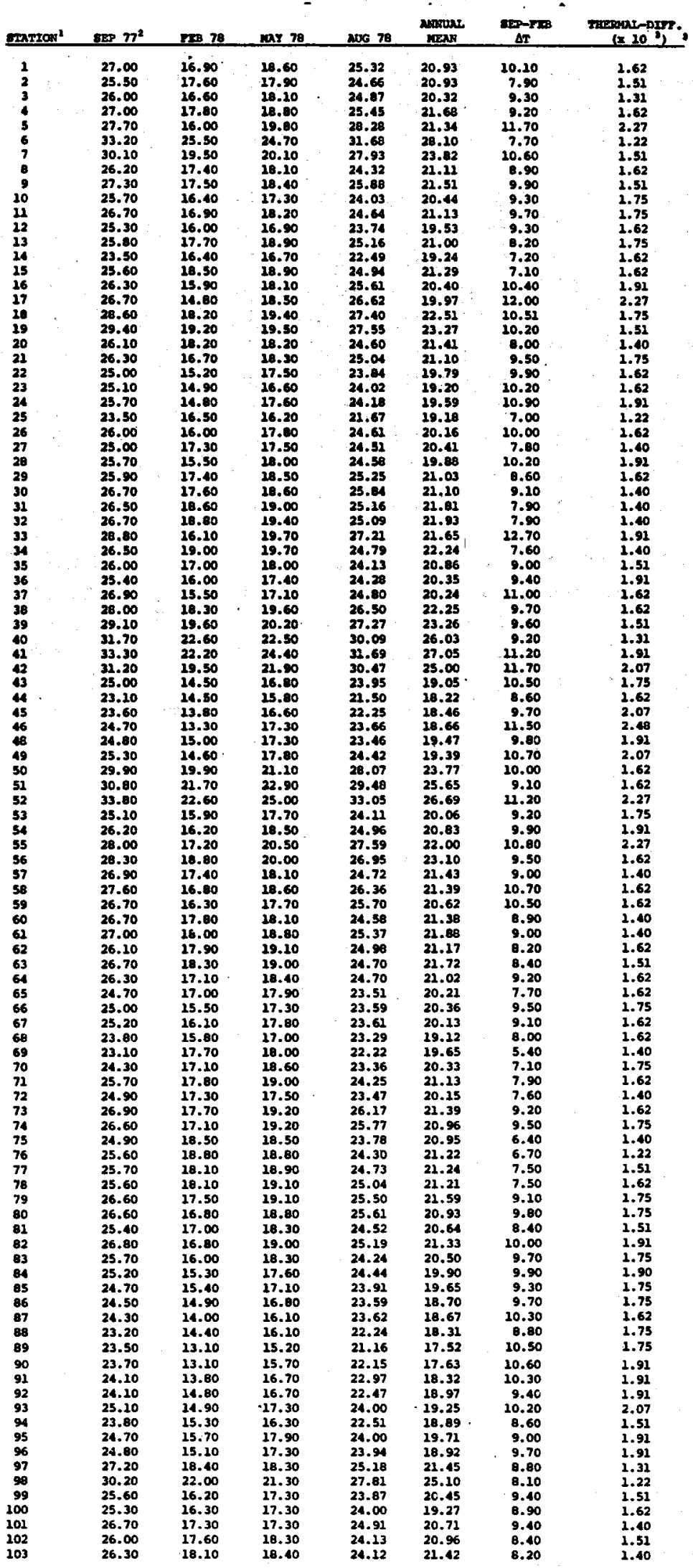

worss, 'wo dats wore taken at gtation 147

Temperature valies in $\mathrm{PCl}$ heve all been corrected for ulevation differencen. corrections based on an adiabutic lapes rate of $-1,0^{\circ} \mathrm{c} / 100$ a correctione tㅡ iㅡ (1977)).

the the (1977)1. 
annual solar cycle, one year, or $3.154 \times 10^{7} \mathrm{sec}$. The values of thermal diffusivity, $\alpha$, for each site were then computed and are listed in Table $1^{x}$. From those values a contour map of thermal diffusivity was prepared (Figure 5). From each annual curve we also computed the annual mean temperature at 2-m depth. These values corrected for elevation are also listed in Table 1 and are contoured in Figure 6 .

An examination of Figures 5 and 6 is useful. The mean temperature map has the "cleanest" temperature contours compared with any of the temperature maps recorded quarterly; over a 12-month period, surface variations have largely averaged out. The mean annual temperature map is the ideal map to be obtained from 2-m temperature data. It is not practical for exploration purposes, however, since a year's data must be collected; it is useful in the present study. When the mean temperature map is compared with the thermal diffusivity map little correspondence can be seen because thermal diffusivity variations are purely a function of the near surface $(0-2 \mathrm{~m})$ soil conditions. On the other hand, the thermal diffusivity values, except in the faulted area where the structure generates sharp contrasts (see section 5), produce broad, smooth contours which strengthen our assumption that thermal diffusivity values have physical significance.

Though the range of thermal diffusivities at Coso is relatively small, they do effect significant temperature variations at a depth of $2 \mathrm{~m}$. It is instructive to examine these time variations in temperatures from place-to-place, especially between September and February when the greatest differences occur. These temperatures are listed in Table 1. A temperature difference contour map for September-February (plotted in Figure 7) shows temperature differences ranging from 5.4 to $12.7^{\circ} \mathrm{C}$. From this presentation, it can be seen that there is a resemblance between the patterns of the temperature difference map and the thermal diffusivity map. From this comparison, the annual spread of temperature differences that are likely to occur in other locations with similar surface meteorological conditions can be predicted.

4. Correcting 1-m Temperature Data at Upsal Hogback for Thermal Diffusivity Variations: An example of the Importance for Making Corrections where the Temperature Anomaly is Small

Olmsted (1977) has reported 1-m temperature data taken at Upsal Hogback, Nevada (near Carson Sink), in June, October and December, 1975. These data were recorded at a site where temperature data for a number of 30-m holes were available. He compared the uncorrected $1-\mathrm{m}$ temperature data for December with the 30-m data and concluded that without making 

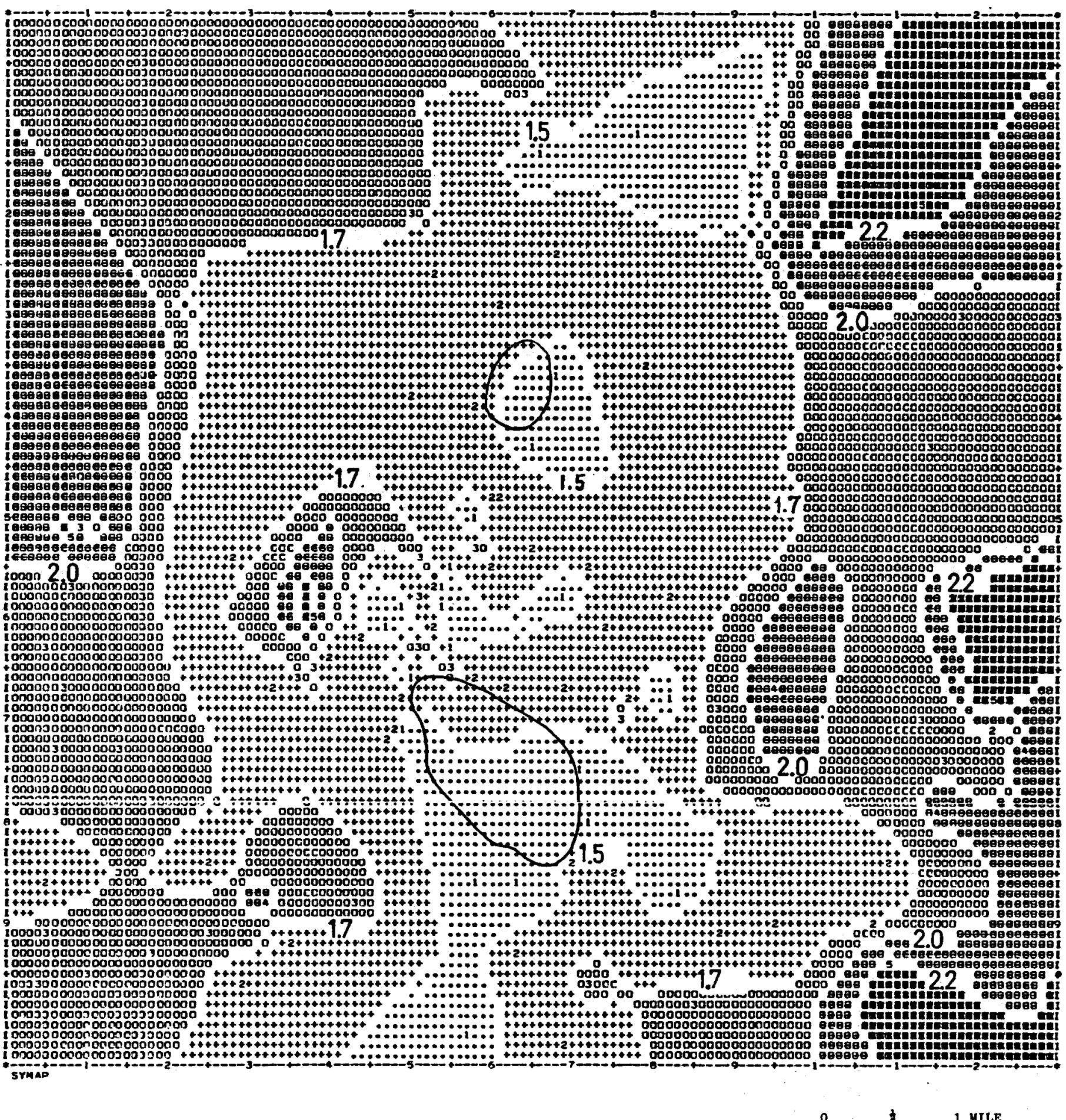

FIGURE 5: Thermal diffusivity $\left(\mathrm{cm}^{2} / \mathrm{sec} \times 10^{3}\right)$ contour map for Coso, integrated from the surface to $2 \mathrm{~m}$. 

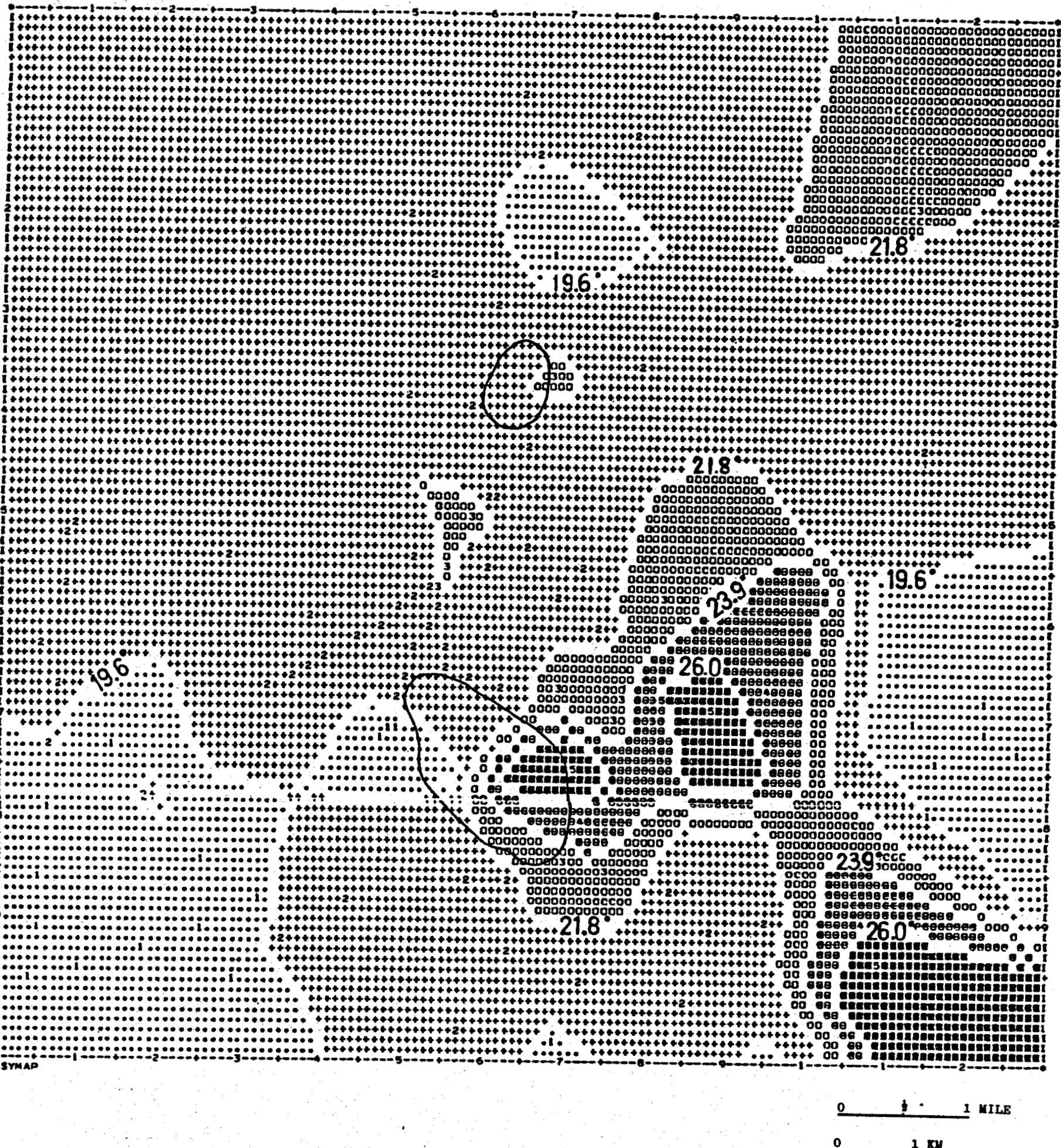

FIGURE 6: Mean annual temperature contour map for Coso, corrected for elevation. Temperature in ${ }^{\circ} \mathrm{C}$. 

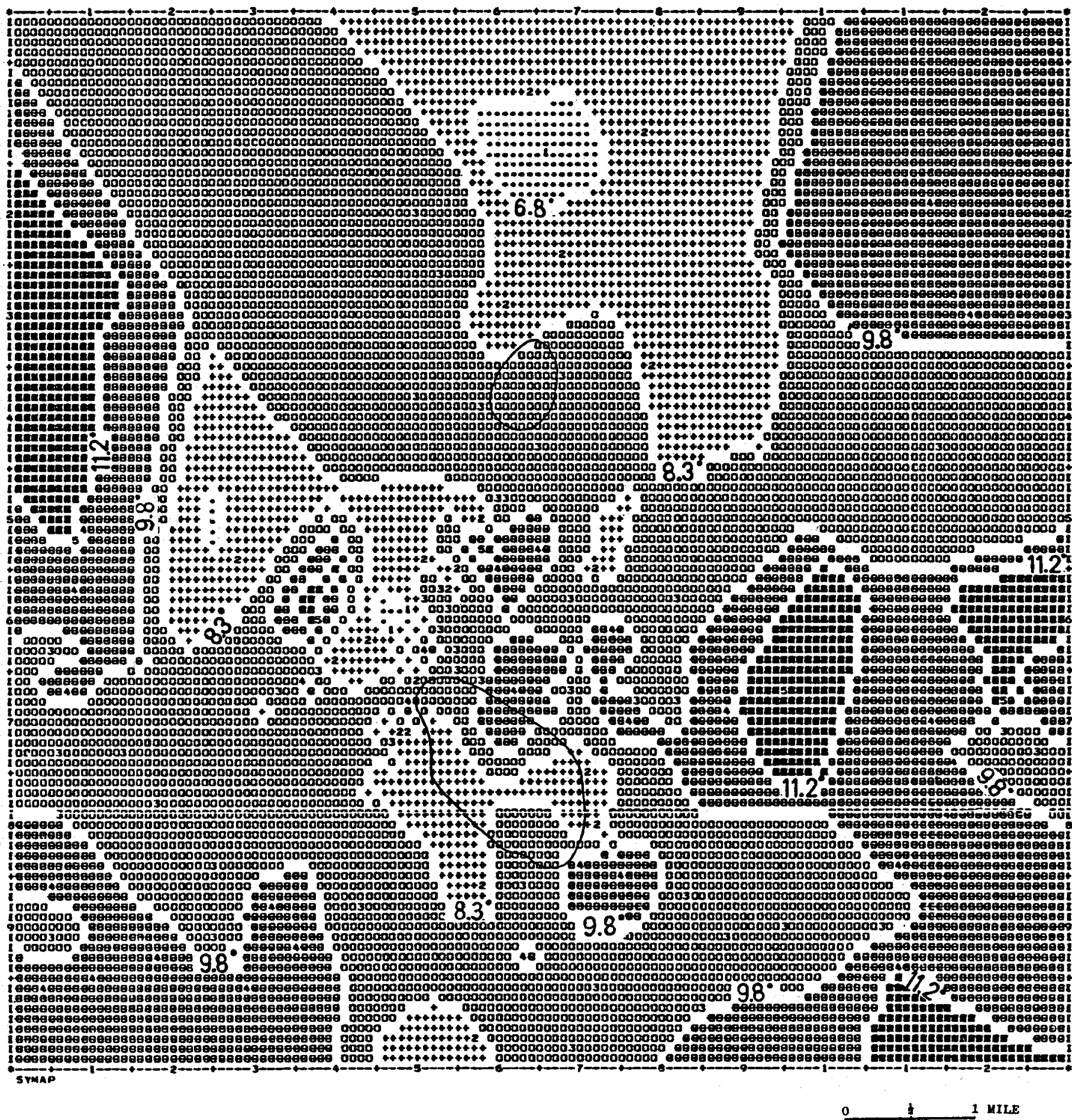

1 MILE

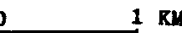

FIGURE 7: September 1977-February 1978 temperature difference map for Coso. Temperature in ${ }^{\circ} \mathrm{C}$. 
proper corrections for the shallow temperature data there is no meaningful correlation that would be useful for predicting the observed anomaly at $30 \mathrm{~m}$. The compared 1- and 30-m data are shown in Figures 8 and 9 .

Having examined the effects of thermal diffusivity at Long Valley and Coso, respectively 150 and $240 \mathrm{miles}$ south of Upsal Hogback, and recognizing some similarities in the geologic settings, we then asked if corrections to olmsted's data could be derived from the information he presented (Olmsted, 1977); and, if so, would the corrected data be more useful in targeting the 30-m anomaly than the uncorrected data.

Examination of the 1-m temperature data presented by Olmsted shows that eight points are common to the June, October and December temperature maps. From these maps we have estimated the temperatures for the elght points and listed them in Table 2. There are not sufficient data during the year to calculate the thermal diffusivities at these points, but it appears from Table 2 that the first three data points with a mean $\Delta t$ of $9.1^{\circ}$ may have a significantly higher thermal diffusiyity than the remaining five points with a mean $\Delta t$ of $6.4^{\circ} \mathrm{C}$. We have assumed the five points with the lower $\Delta t^{\prime}$ s represent the thermal diffusivities of the majority of the data points used to prepare Olmsted's December map (Figure 8), 1.e., the majority of the data points have essentially the same thermal diffusivity. Accordingly, because it is clear that the first three data points have significantiy higher thermal diffusivities than the majority, we eliminated them from Olmsted's December data set and recontoured the December 1-m temperature map. Figure 10 shows the new contour map with elevation corrections (although these were relatively sma11). The SYMAP program was used to contour these data and avoid personal bias. From comparison, we have recontoured Olmsted's $30-\mathrm{m}$ data by the SYMAP program (Figure 11). Comparing the two maps with corrections for surface effects, Olmsted's $1-\mathrm{m}$ temperature data correlate well with the $30-\mathrm{m}$ temperature anomaly and would have been useful for targeting the deeper anomaly. Olmsted (1978) later confirmed our interpretation, indicating that he had taken additional data (unpublished) at his site for a complete annual cycle. His mean annual $1-\mathrm{m}$ temperature contours were consistent with our interpretation shown in Figure 10.

In summary, Olmsted rightly points out that his uncorrected 1-m temperatures do not correlate well with $30-\mathrm{m}$ temperatures at the same location. However, when we correct the data set by removing key data points that do not have the same thermal diffusivity, we get better targeting of the 30-m anomaly. This is additional strong evidence for gathering thermal diffusivity data when making a shallow temperature survey. 


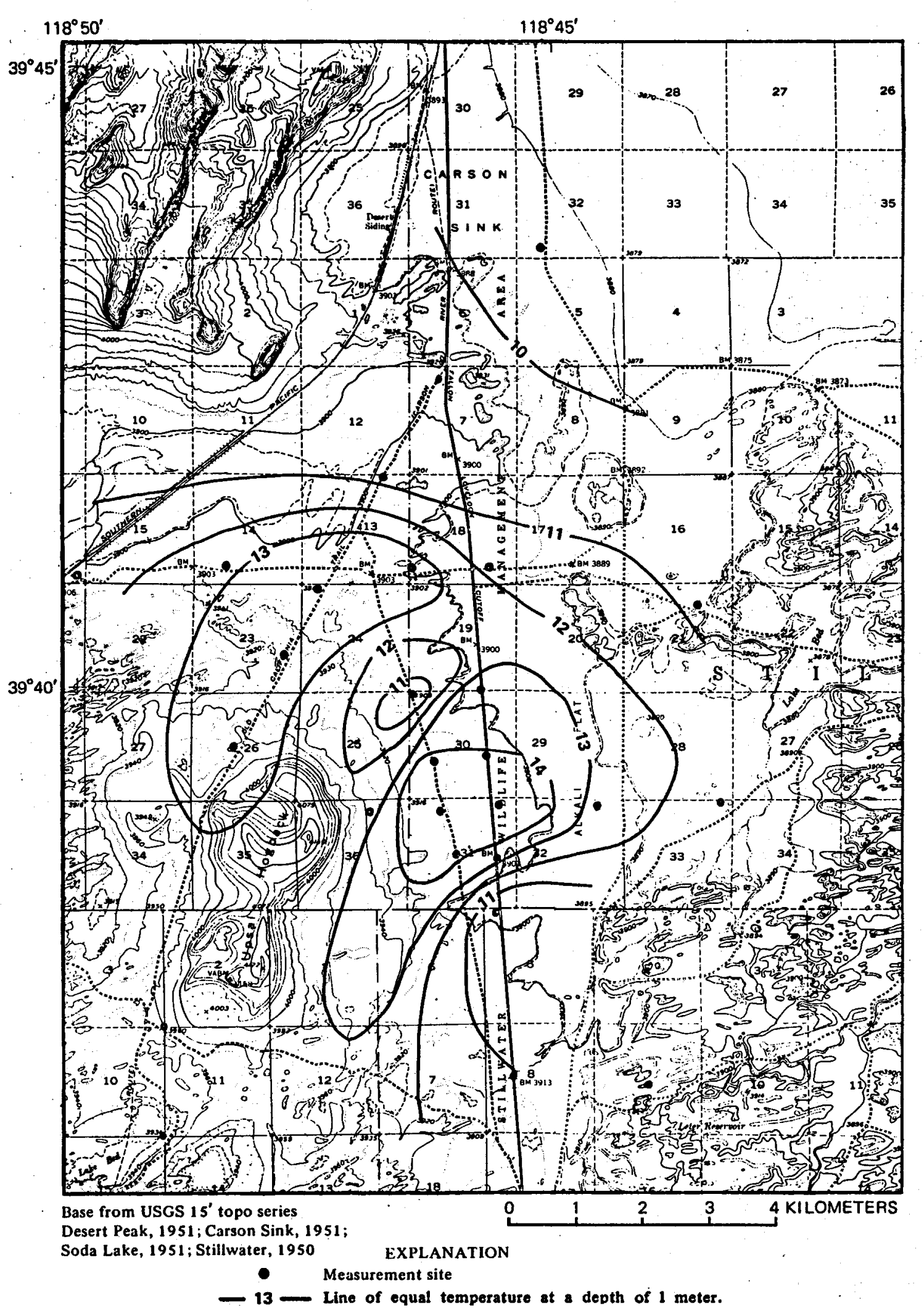

FIGURE 8; Upsal Hogback area showing temperature at a depth of $1 \mathrm{~m}$, December 2, 1975. (after Olmsted, 1977). 


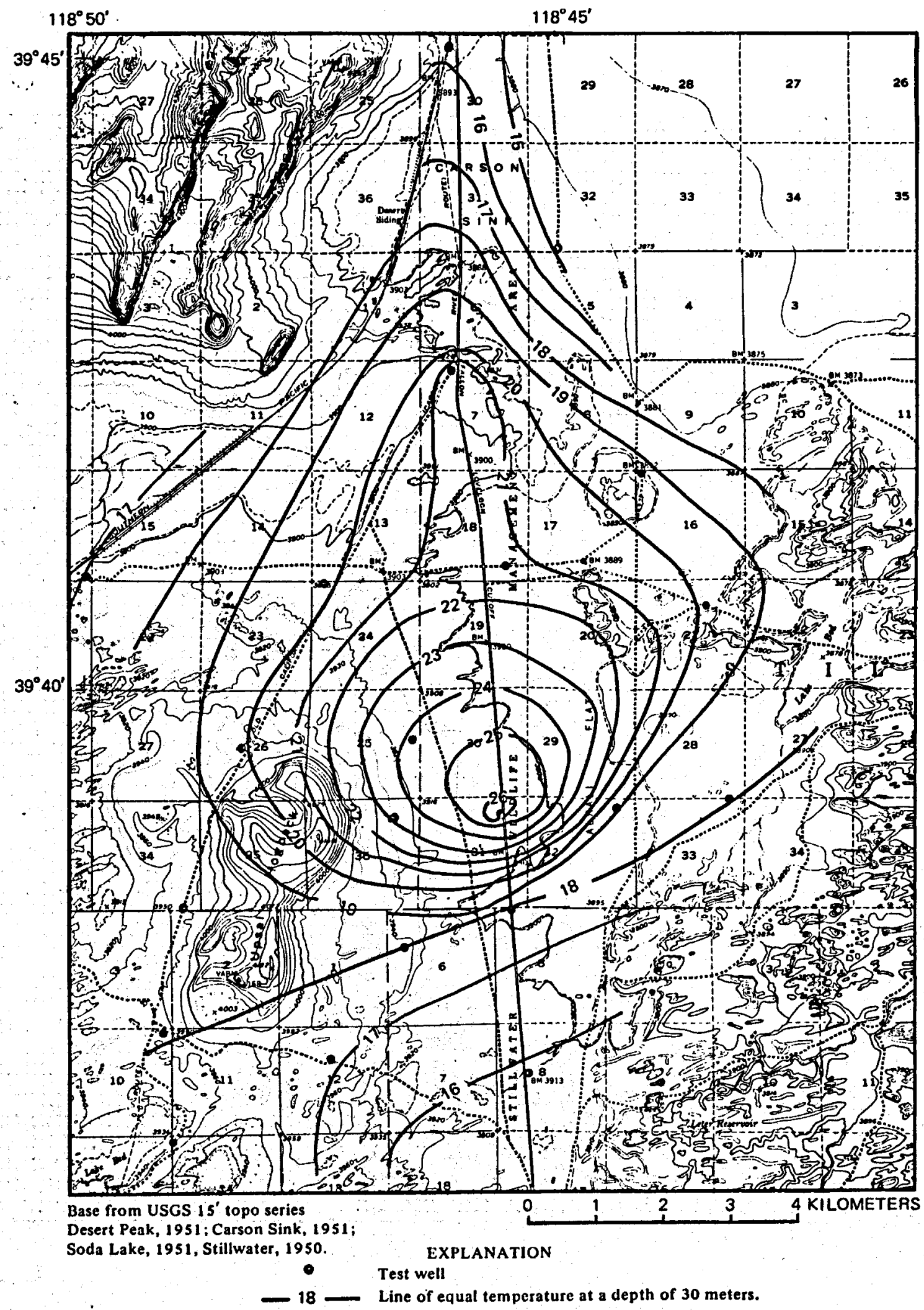

FIGURE 9; Upsal Hogback area showing temperature in test wells at a depth of $30 \mathrm{~m}$, September 1975. (after Olmsted, 1977) 

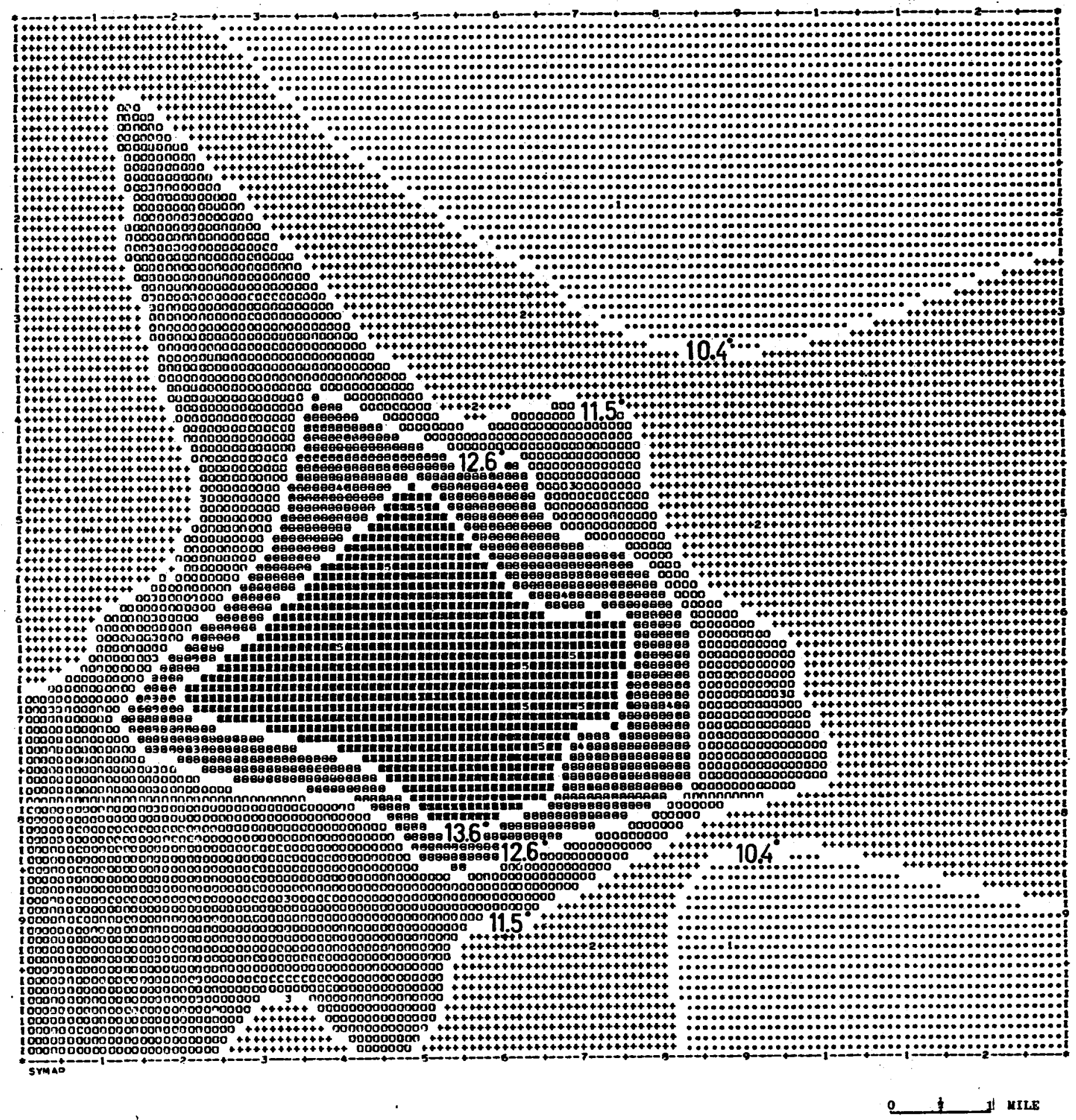

$\underline{0} \quad 1 \quad \mathbf{B M}$

FIGURE 10: Corrected 1-m temperature contour map for Upsal Hogback. Temperature in ${ }^{\circ} \mathrm{C}$. 


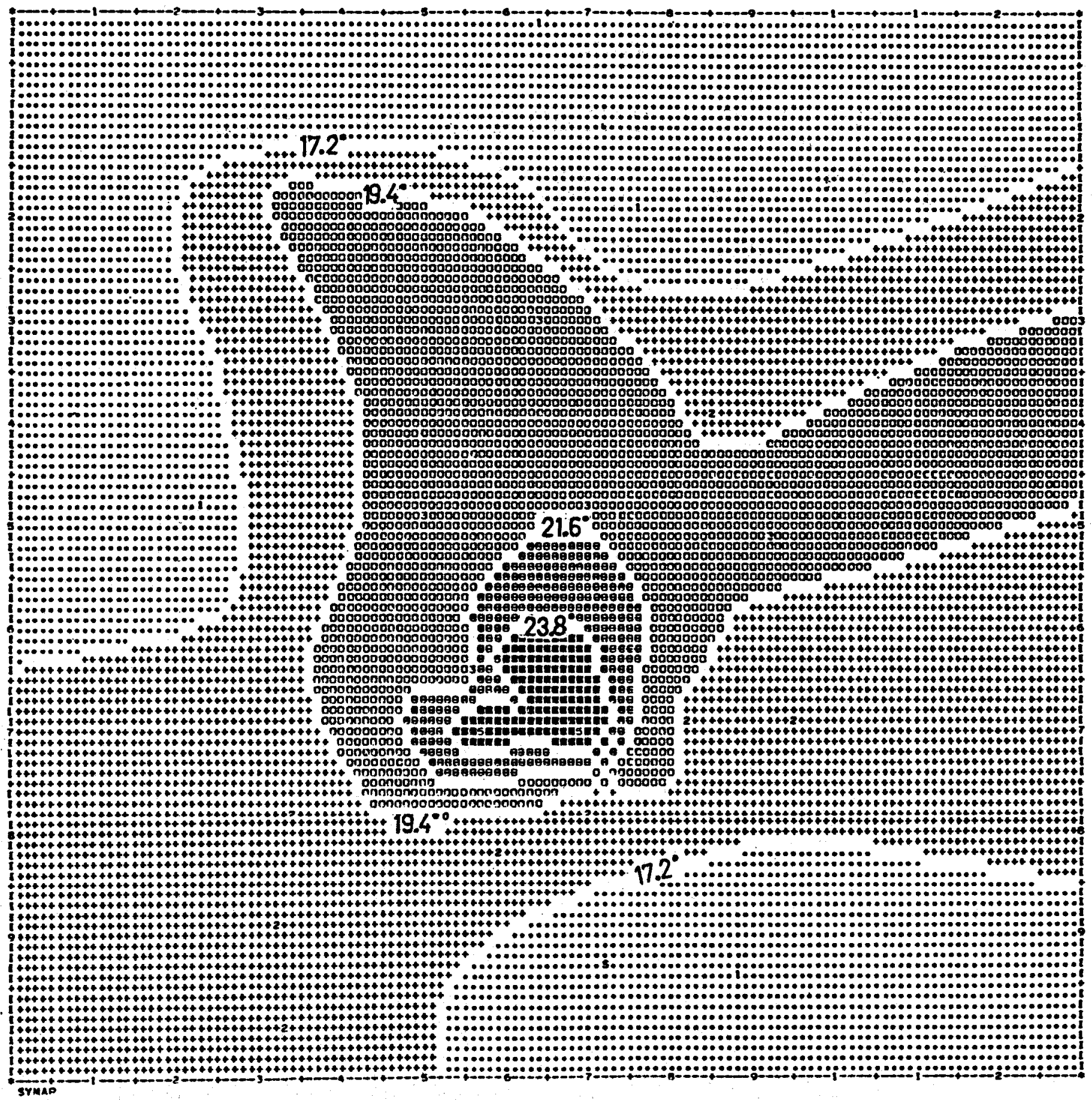

$0 \quad 1 \mathrm{MILE}$

$0 \quad 1 \mathrm{~kat}$

FIGURE 11: 30-m temperature contour map. Data,values derived from contour map shown in Figure 9 . Temperature in ${ }^{\circ} \mathrm{C}$. 


\section{TABLE 2}

TEMPERATURES AT 8 COMMON POINTS AT UPSAL HOGBACK

\begin{tabular}{llllc}
$\begin{array}{l}\text { POINT LOCATION } \\
\text { (Section*) }\end{array}$ & JUNE & $\begin{array}{c}\text { TEMPERATURES } \\
\text { OCTOBER }\end{array}$ & $\begin{array}{l}{ }^{\circ} \mathrm{C} \\
\text { DECEMBER }\end{array}$ & $\Delta$ T(JUN-DEC) \\
30 & 20.8 & 17.8 & 10.8 & 10.0 \\
8 & 18.9 & 15.9 & 10.9 & 8.0 \\
36 & 22.3 & 18.4 & 13.0 & 9.3 \\
\hline 33 & 18.0 & 15.8 & 11.5 & 6.5 \\
18 & 18.8 & 17.3 & 11.9 & 6.9 \\
32 & 19.2 & 18.1 & 12.8 & 6.4 \\
$19 / 30$ & 19.2 & 18.2 & 13.2 & 6.0 \\
31 & 20.4 & 19.3 & 14.4 & 6.0
\end{tabular}

*See Olmsted (1977) Figure 13 
5. Comparison of our 2-m Temperature Data at Coso with other Geological and Geophysical Data

Other researchers independently have gathered geologic and geophysical data at Coso that appear wholly consistent with our data. Electrical resistivity surveys (Fox, 1978a) and low altitude aeromagnet1c surveys (Fox, 1978b) show anomalies coincident with our shallow temperature anomaly. A mapping of surface hydrothermal alteration products coincides with our temperature anomaly. These coincident anomalies are shown In Figure 12, prepared by Hulen(1978).

As shown in LeSchack et al (1977), shallow temperature measurements can define faults intersecting the surface. Using the technique described by Poley and Van Steveninck (1970), we identified faulting first suggested by O'Hara (1977) from unpublished photo-interpretation and field geology data. Since Poley and Van Steveninck (1970) suggested that variations in temperatures over fault traces would be due primarily to thermal conductivity contrasts, we examined the computed thermal diffusivities along the two profile lines $A-A^{\prime}$ and $B^{\prime} B^{\prime}$, shown in Figure 13. The thermal diffusivities increased markedly over suspected fault trace zones (Figure 14). We assume this is caused by brecclated fault zones having a higher moisture content than the surrounding area and, hence, greater thermal diffusivity.

The faults interpreted by thermal diffusivity variations are consistent with the fault structure implied by O'Hara (1977), though the present interpretation differs somewhat from our original interpretation (LeSchack et al 1977). We favor the interpretation derived from thermal diffusivity data rather than temperature data alone, since tracing similarities from one profile line to the other is more easily accomplished using thermal diffusivity values. An electrical resistivity mapping of the area (Fox, 1978a) shows an unusual contour configuration between 50 and 100 ohm-meters with the same geometry and position as the faults identified by thermal diffusivity (Figure 15). Fox (1978c) says this is consistent with his interpretation of the Vshaped 50-100 ohm-meter contour pattern. He believes the $V$ marks the western boundary of the rhyolite intrusion, i.e., Sugarloaf Mountain. 


\section{R38E | R39E}

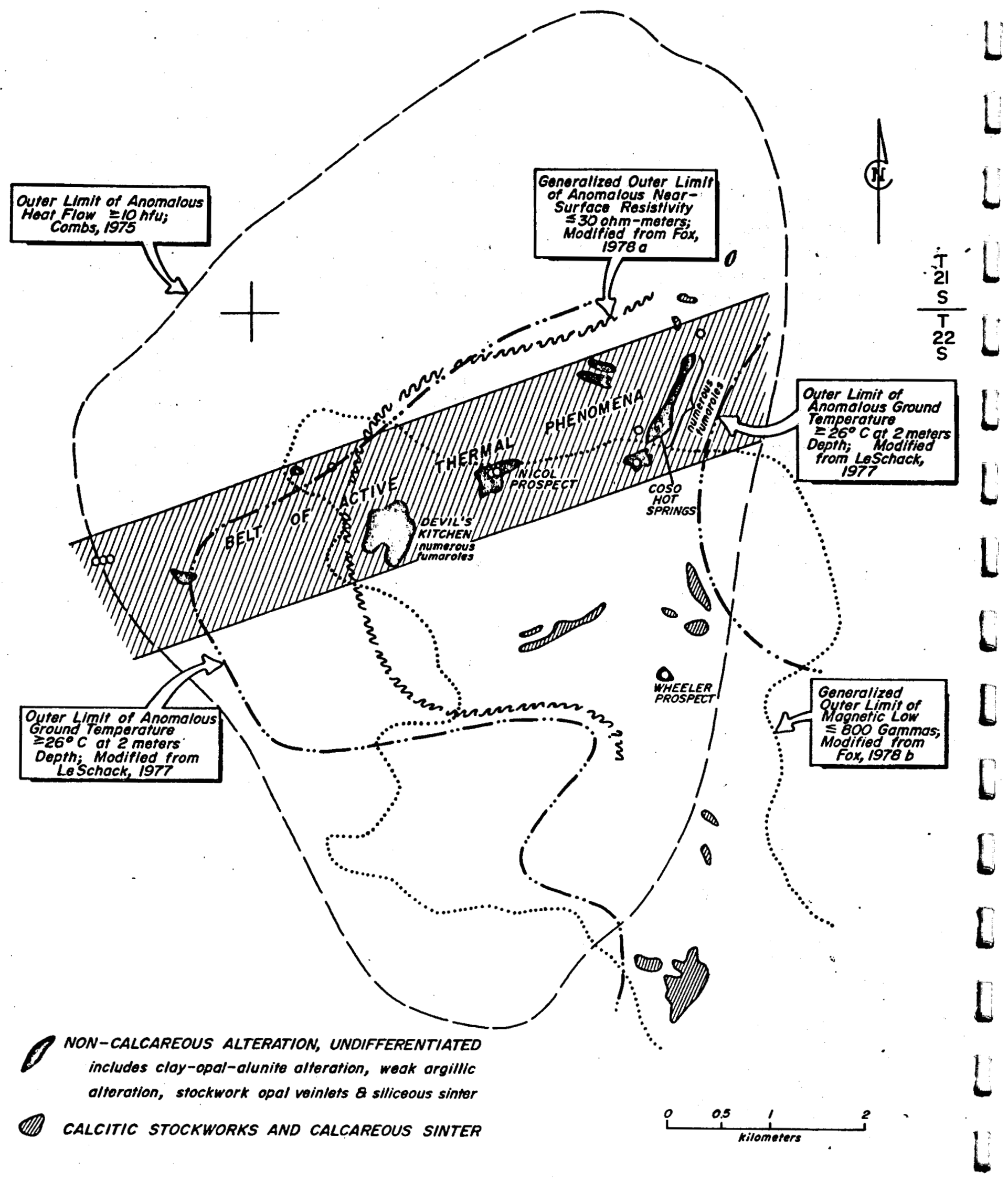

FIGURE 12: Generalized Alteration and Geophysical Map of Coso (after Hulen, 1978) 


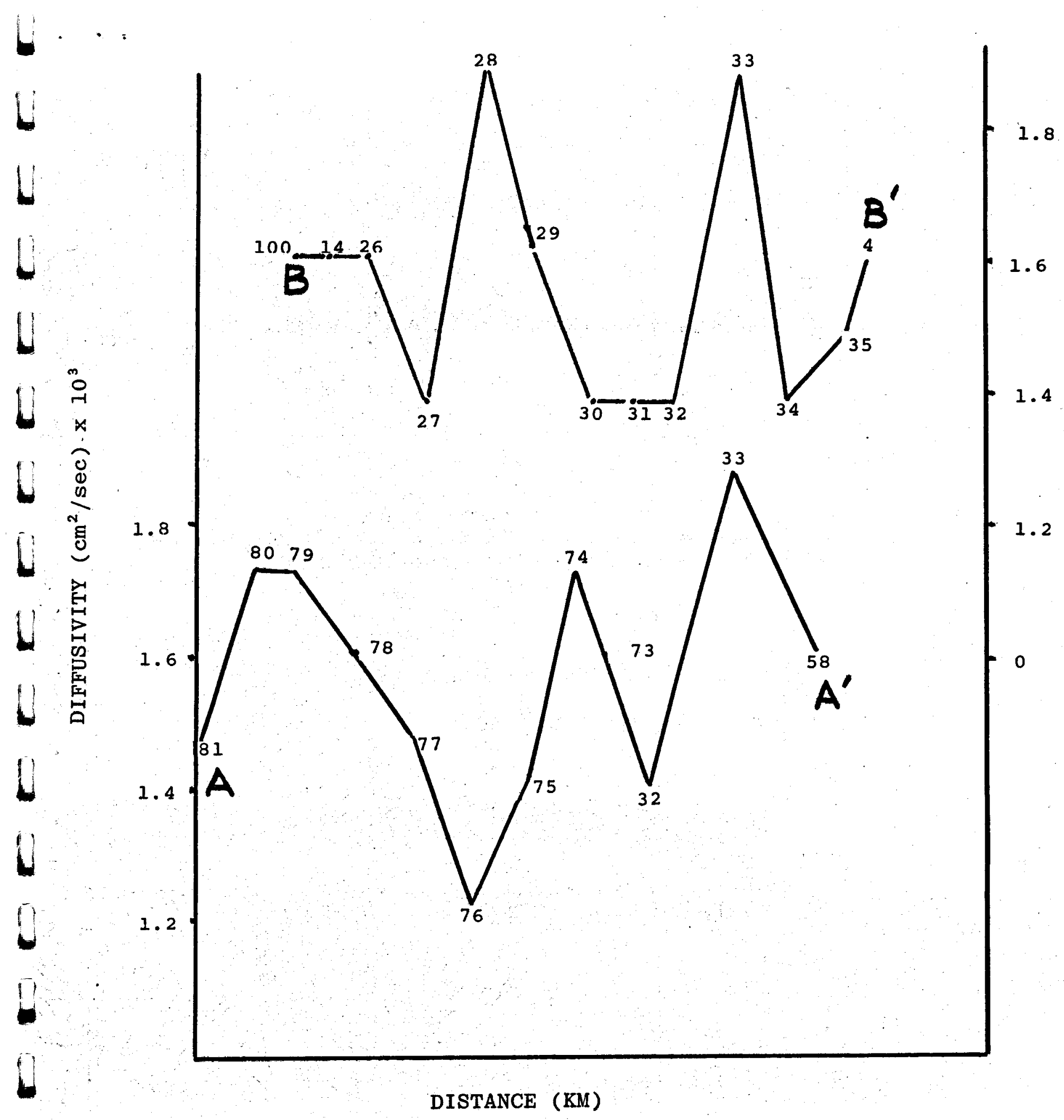

FIGURE 13: Thermal diffusivity profiles along transects $A-A^{\prime}$ and $B-B^{\prime}$. (see Figure 14) 


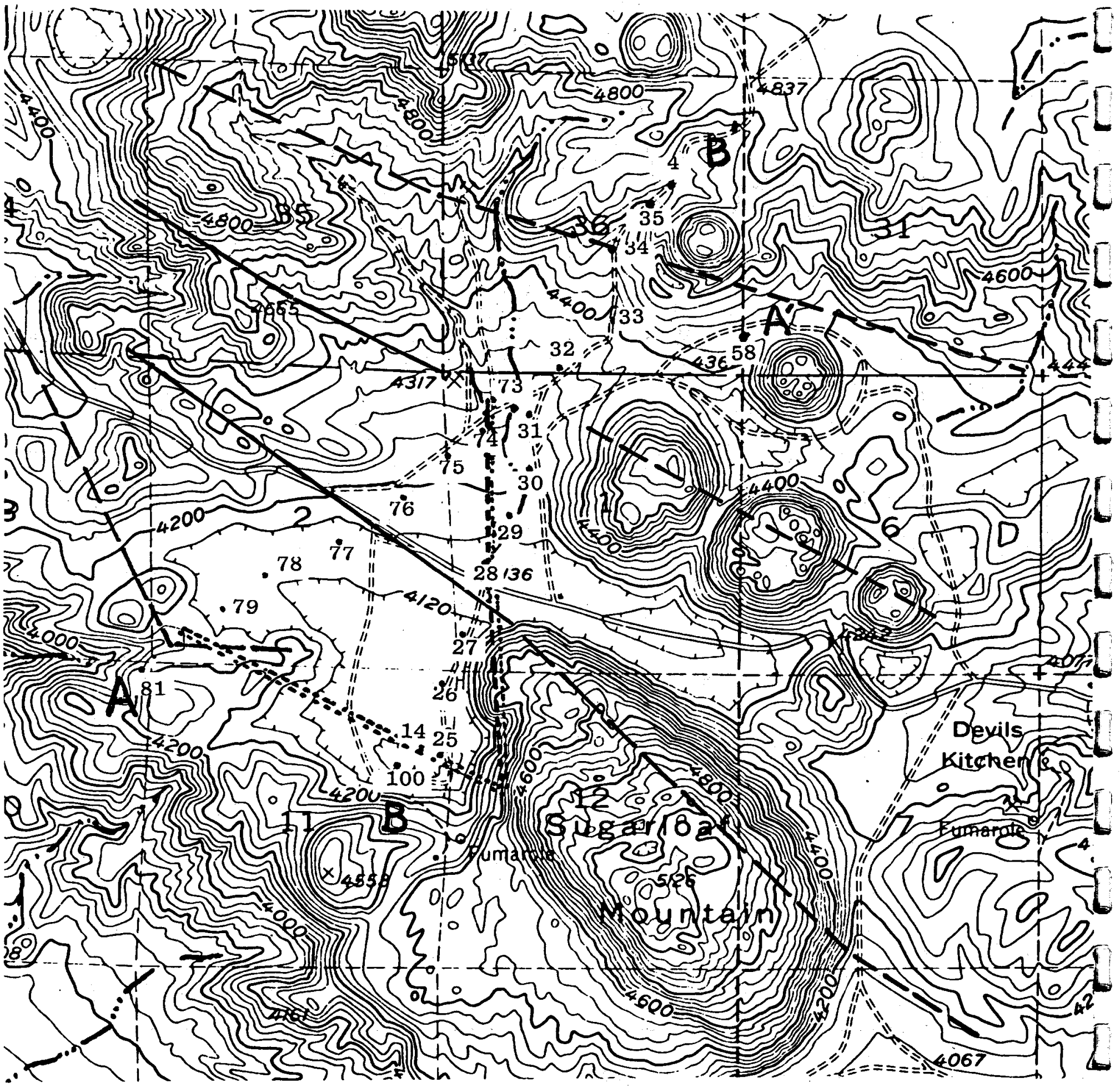

FIGURE 14: Faults at Coso suggested by O'Hara (1977) are indicated by solid and dashed lines. Profiles $A-A^{\prime}$ and $B^{\prime} B^{\prime}$ are indicated by dotted lines. Double dashed lines are faults suggested by correlation of thermal diffusivity. 


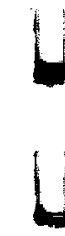

1 i Restravation

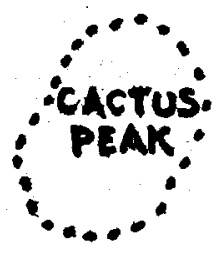

$b$
$b$
$b$
$L$
$L$
$L$ GOUNDARY
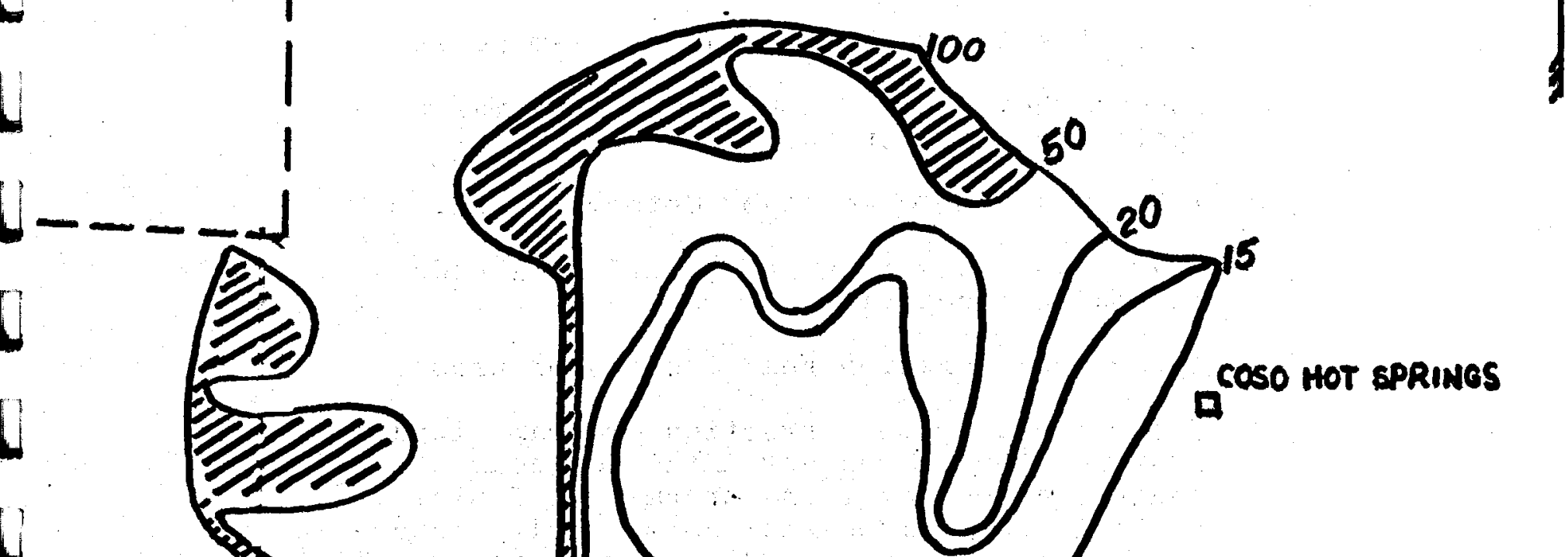

MagLOAF: mecurian
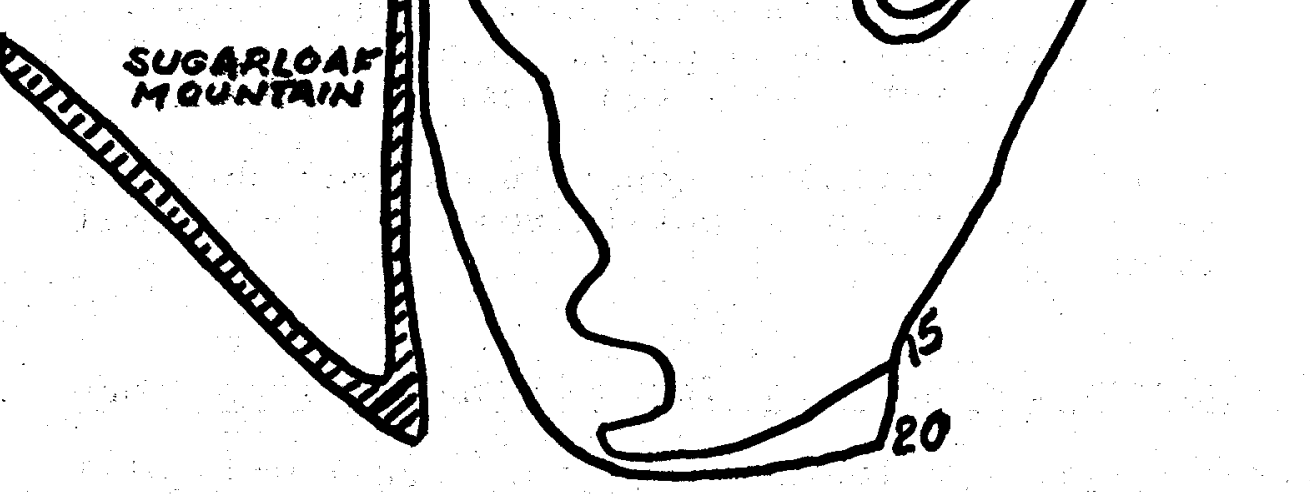

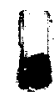

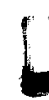

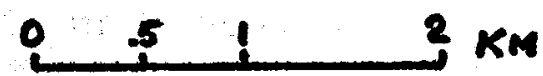

FIGURE 15: Electrical resistivity anomaly at Coso, after Fox (1978a). Note the similarity of shape and location of V-shaped pattern between 50-100 ohm-meters to our fault pattern in Figure 14. 
6. An Outline of a Complete Shallow Temperature Survey

Speed is important when conducting a complete shallow temperature reconnaissance survey.* The luxury of taking sufficient data for computing the mean annual $2-m$ temperatures is not likely to occur, and to be cost-effective, the survey must be completed quickly.

The steps essential to a SHALLOW-TEMP ${ }^{\text {TM }}$ survey are:

(a) At each site drill two adjacent 2-m holes.

(b) Insert thermistor probe in one, thermal conductivity probe in the other.

(c) Take soil sample for type determination.

(d) Measure surface roughness, surface albedo, thermal conductivity.

(e) After equilibration read thermistor probe.

(f) Using annual wave correction program, input 18-24 months of weather data from nearest Weather Bureau Station, thermal diffusivity (calculated from thermal conductivity), surface roughness and albedo. Output is normal 2-m temperature for given location and time.

(g) Subtract normal 2-m temperatures from observed 2-m temperatures to obtain residual geothermal anomaly.

7. Preliminary Tests with a Thermal Conductivity Probe

Differing propagation rates of the annual wave will create temperature differences at $2 \mathrm{~m}$ that mask geothermal temperature anomalies. An integrated value of thermal diffusivity down to $2 \mathrm{~m}$ can be calculated by the temperature phase-lag method if temperature readings for a full year are available. If the object is to conduct a rapid shallow temperature survey it is desirable to have a rapid method for estimating thermal diffusivity in situ when the temperature probes are inserted.

Recognizing that thermal diffusivity is defined by

$$
\propto=\frac{\mathbf{k}}{\rho c}
$$

*We call this complete program a "SHALLOW-TEMP"TM survey. 
where

$$
\begin{aligned}
& \alpha=\text { thermal diffusivity } \\
& k=\text { thermal conductivity } \\
& \rho=\text { bulk density } \\
& c=\text { specific heat }
\end{aligned}
$$

we have attempted to estimate thermal diffusivity in the field by measuring $k$. The parameters $\rho$ and $c$ are soil characteristics and tend to be conservative over a relatively wide range of soll conditions, especially when the moisture content is low. As a result, the thermal diffusivity in most cases is largely a function of thermal conductivity. The value of $\rho$ can be determined by taking a soil sample at each site, or if the soll description is known, from the literature. The value of $c$ is most conveniently obtained from the literature.

Using Hooper and Lepper (1950) as a guide, a thermal conductivity probe was constructed as shown in Figure 16 . A 24-in $(61-\mathrm{cm})$ lexan core was wound with $38 \mathrm{ft} 10 \mathrm{in}$ $(11.8 \mathrm{~m})$ of 18 AWG solid copper wire (Belden 8528-100) such that the winding occupied 23.25 in $(59.1 \mathrm{~cm})$ of the core. At the mid-point of the core two thermistors (VECO P32A178) were emplaced (one is used; the other is a backup). This core is inserted into a copper tube $283 / 8$ in $(72.1 \mathrm{~cm})$ long and 0.6 in $(1.6 \mathrm{~cm})$ in diameter. A pointed steel plug is attached to one end. With the probe inserted into a relatively undisturbed soil section, a known electric current heats the core.

Heat is radiated outward as a function of the thermal conductivity of the surrounding material. Thermistor resistance is recorded each minute for about 20 minutes and measures the rate at which heat induced by the probe is dissipated. Resistance measurements converted to temperature are plotted against the $10 \mathrm{~g}$ of time; these plots are used to compute the thermal conductivity.

We conducted a field experiment at Long Valley to evaluate use of a thermal conductivity probe (described above) for operational field surveys. At the four locations where we had left 6-element thermistor probes for a year, i.e., Base Station, and sites 5, 11 and 21 , we emplaced the probe and made thermal conductivity measurements. As presently constructed, the probe is designed to be inserted vertically into a $0.6 \mathrm{in}(1.4 \mathrm{~cm})$ augered hole. In our preliminary experiment, this could only be accomplished at the Base station because of the large pebbles intermixed with the soil, and then only to a depth equal to the length 


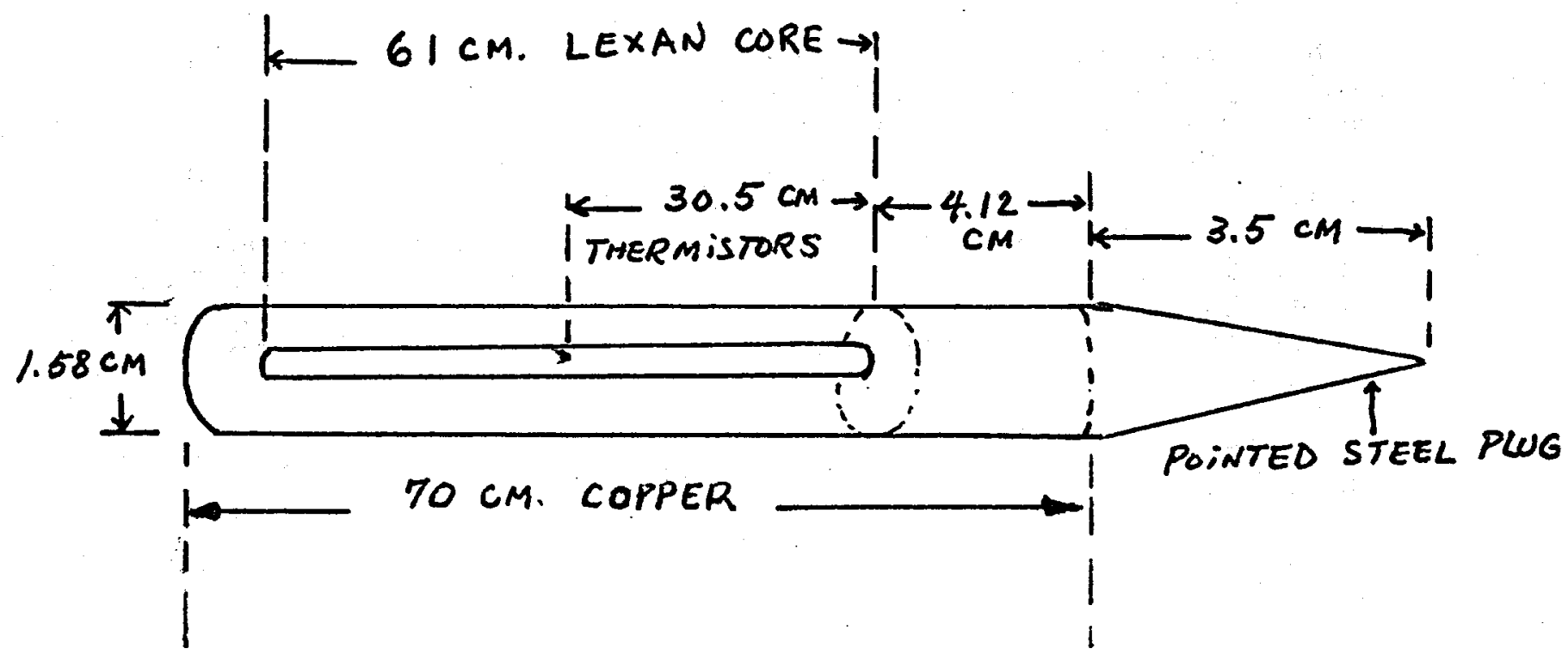

FIGURE 16: Diagram of thermal conductivity probe designed by Lewellen. 
of the probe. This meant thermal conductivity measurements were centered at the mid-point of the probe, $33 \mathrm{~cm}$. At other sites the preponderance of pebbles prohibited even a modest (1.4) cm auger hole. However, using a pick axe we trenched to a depth of $33 \mathrm{~cm}$ at sites 5 and II (comparable to the depth at the Base Station). At Site 21, an indurated layer at $25 \mathrm{~cm}$ stopped us. When trenching, the procedure was to scrape down to the desired depth, leaving an undisturbed layer at the bottom. The probe was placed horizontally on the undisturbed bottom layer and the trench was backfilled. We tamped the soil to a density estimated to be similar to the undisturbed section. After completing measurements at stations 5,11 and 21 , we returned to the Base Station and, for comparison, made a $33 \mathrm{~cm}$ trench measurement next to our vertical probe site. Temperature vs time for these sites are plotted in Figures 17-20..

From these plots it is clear where the slope first changes. According to Hooper and Lepper (1950), using any two temperatures that lie along the curve comprising the first change in slope, we can determine thermal conductivity according to the following relationship:

$$
k=\frac{0.019 I^{2} R \ln \left(t_{2} / t_{1}\right)}{\theta_{2}-\theta_{1}}
$$

where

$$
\begin{aligned}
& \mathrm{k}=\text { thermal conductivity in } \mathrm{cal} / \mathrm{sec} \cdot{ }^{-} \mathrm{cm} \cdot{ }^{\circ} \mathrm{C} \\
& I=\text { current in amperes } \\
& \mathbf{R}=\text { resistance/unit length of probe in } \Omega / \mathrm{cm} \\
& t=\text { time in seconds } \\
& \theta=\text { temperature in }{ }^{\circ} \mathrm{C}
\end{aligned}
$$

Using Equation 3 , we evaluated the thermal conductivity for the four Long Valley sites. These values, along with associated soil parameters, are listed in Table 3 . Examination of these soil parameters indicates that, as a first approximation, the soils at each site can be considered in the category quartz sand with $8.3 \%$ moisture, which according to Ingersolf et al (1954), has a specific heat, $c$, of $0.24 \mathrm{cal} / \mathrm{gm}$. ${ }^{C} \mathrm{C}$ and a bulk density, $\rho$, of $1.75 \mathrm{gm} / \mathrm{cm}^{3}$. From these values, $1 . e,, k, \rho$ and $c$, we computed thermal diffusivity for each of the four sites at Long Valley. As shown in Table 4 , the thermal diffusivities computed using the measured thermal conductivities compare favorably with those computed by means of phase lags of the diurnal wave.*

*See Appendix $B$ for data. 


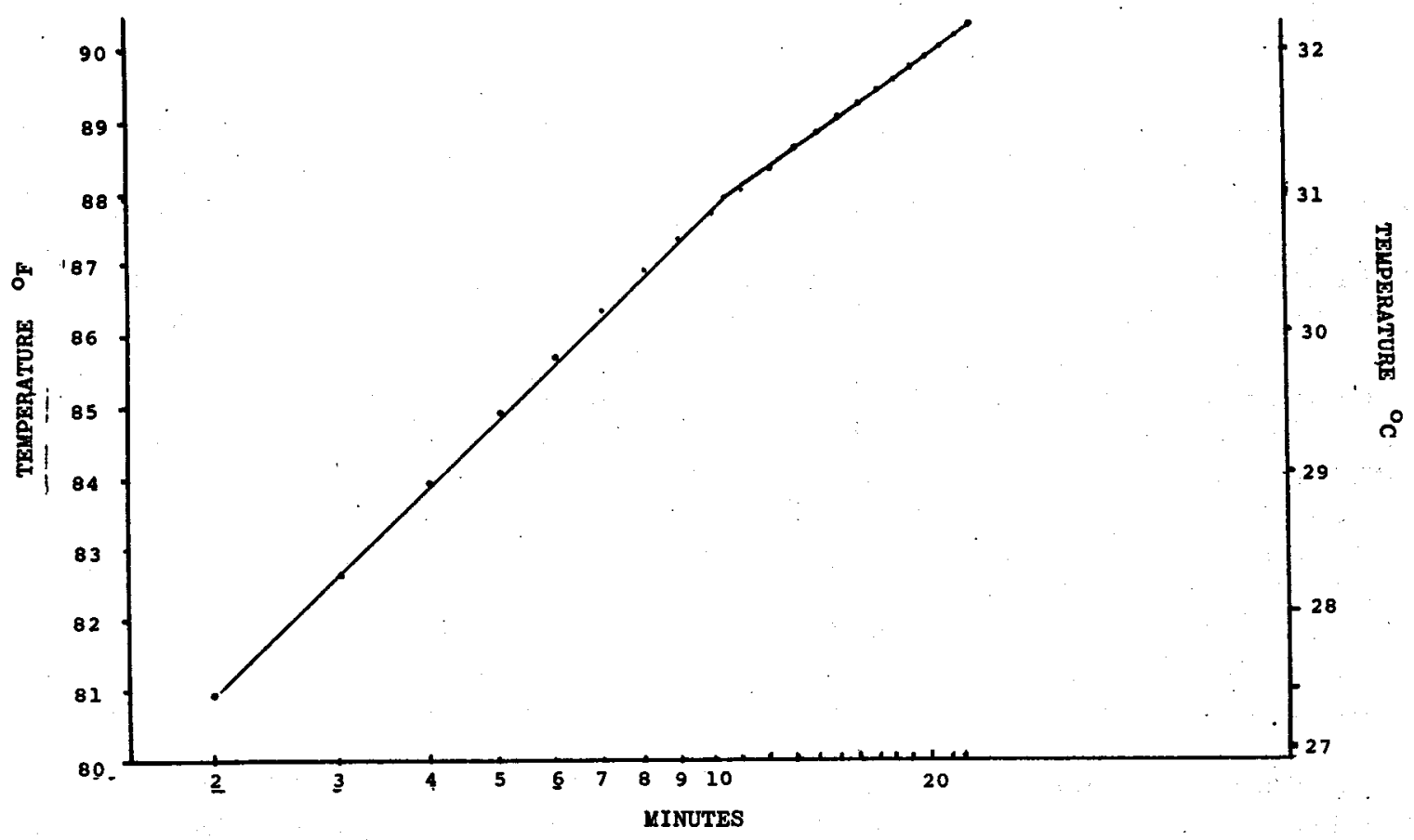
FIGURE 17: Temperature vs time curve for Lewellen thermal conductivity probe at $33 \mathrm{~cm}$
depth at Base Station, Long Valley August 1978

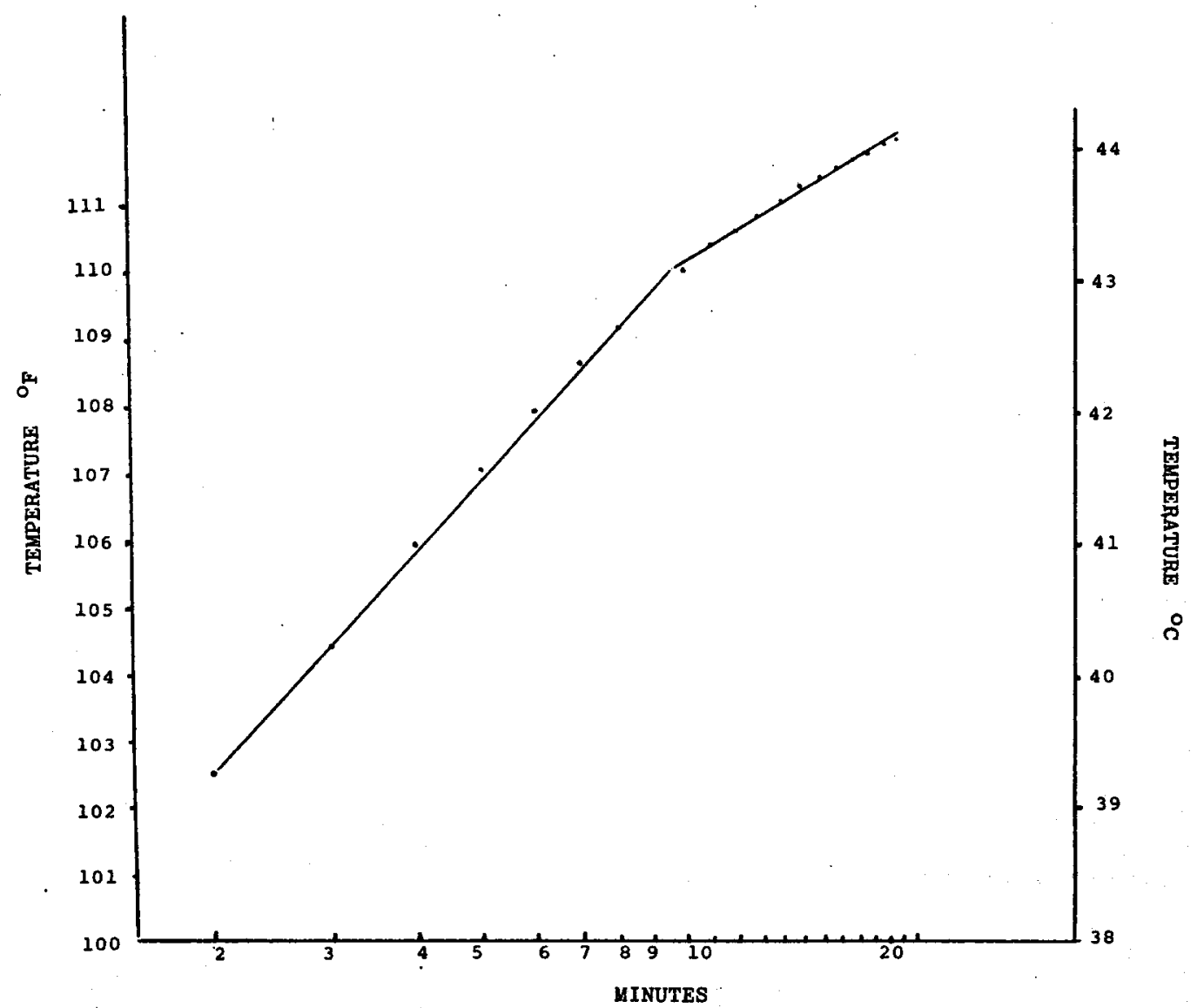

FIGURE 18: Temperature vs time curve for Lewellen thermal conductivity probe at $33 \mathrm{~cm}$ depth at Station \#5, Long Valley August 1978

28 


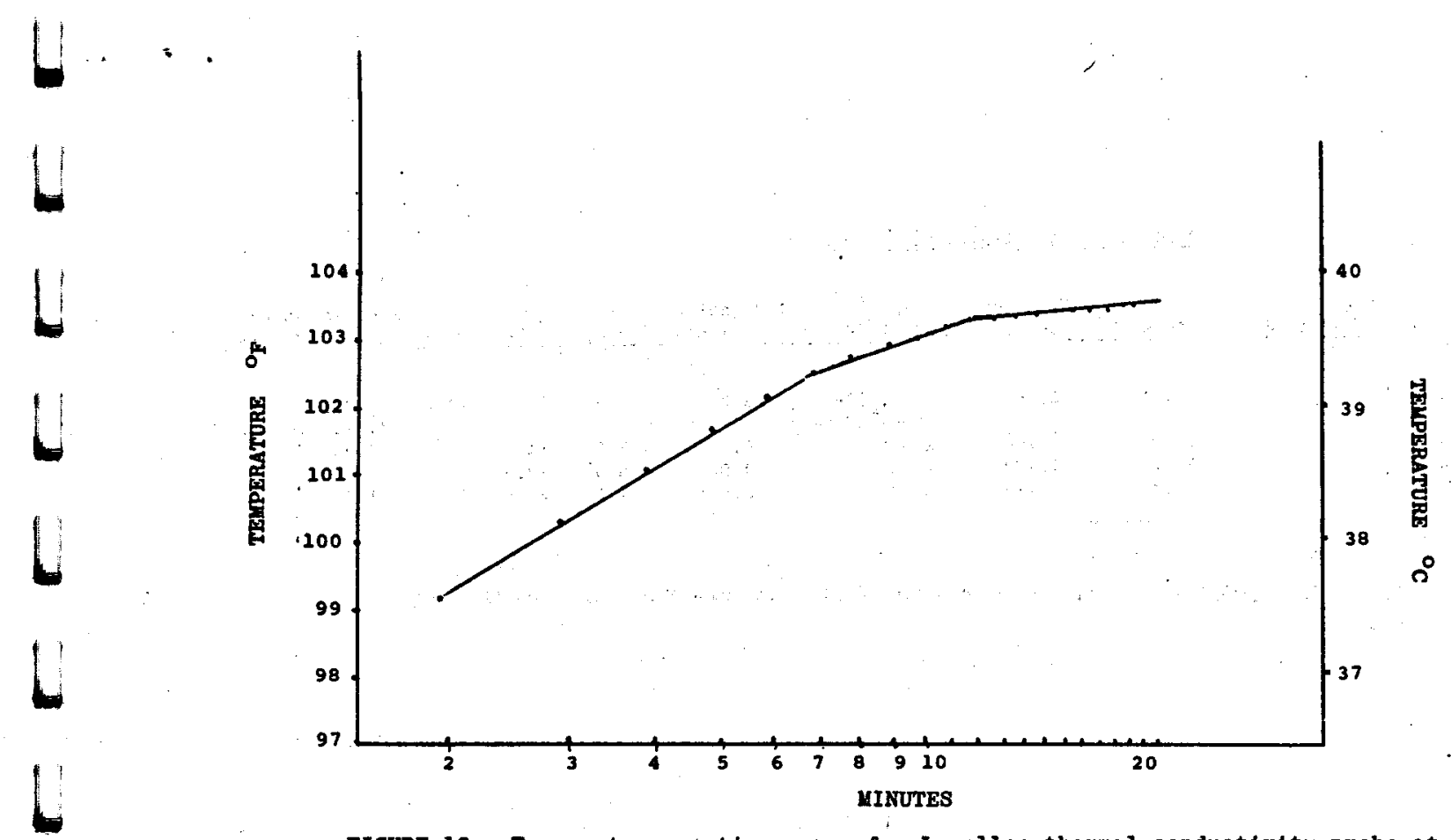

FIGURE 19: Temperature ve time curve for Lewellen thermal conductivity probe at $33 \mathrm{~cm}$ depth at station $\# 11$, Long Valley, August 1978.

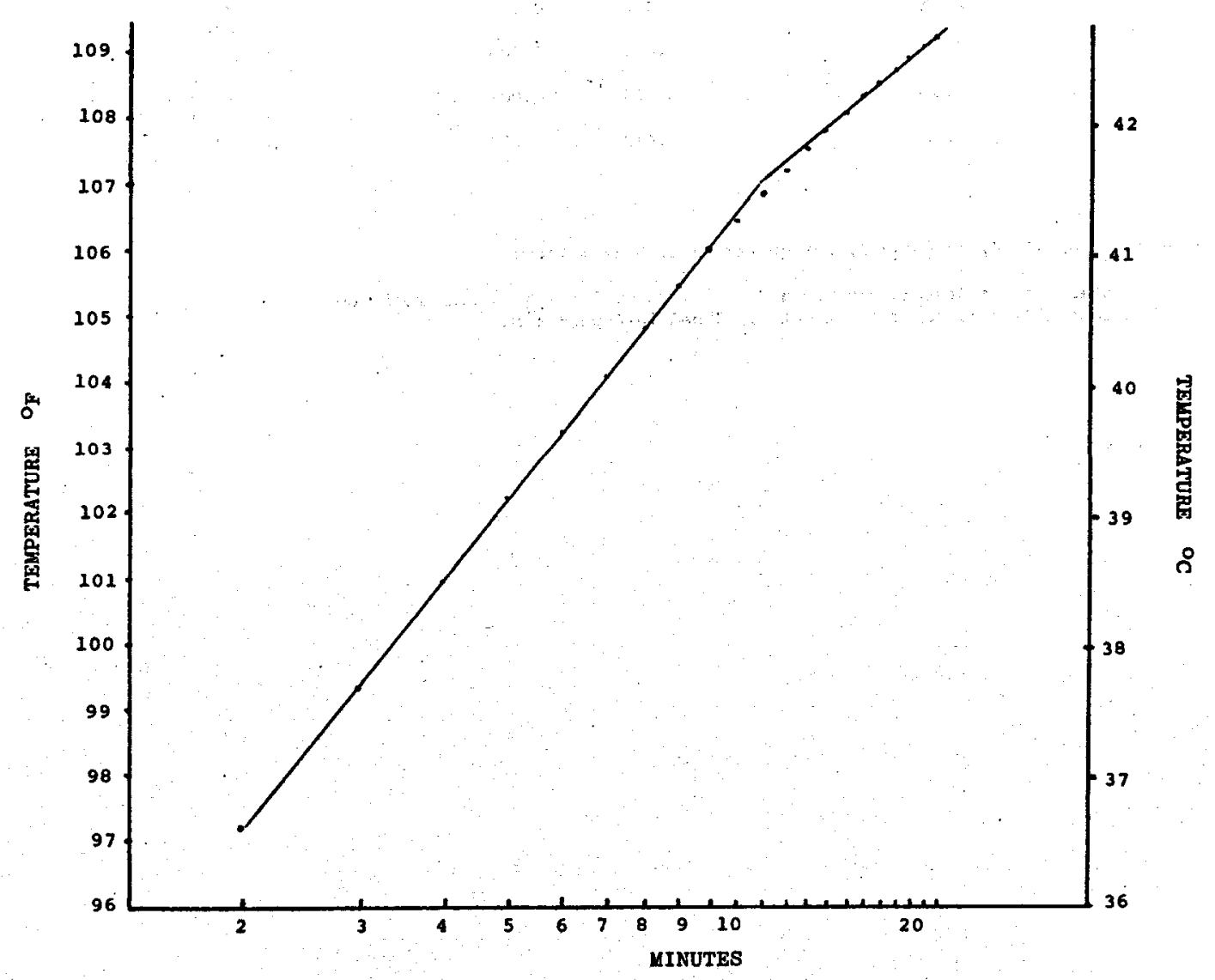

FIGURE 20: Temperature vs time curve for Lewellen thermal conductivity probe at $25 \mathrm{~cm}$ depth at Station \#21, Long Valley, August 1978. 
mance 3: Long Valley soll parameters

\begin{tabular}{|c|c|c|c|c|c|c|c|c|c|c|}
\hline STATION & $\begin{array}{r}n \\
\text { Jor } 1977 \\
\end{array}$ & $\begin{array}{l}\text { er } \\
\text { AUG } 1978 \\
\end{array}$ & Gravel & $\begin{array}{c}\text { Balk Density } \\
\text { JuL } 1977 \\
\end{array}$ & $\begin{array}{l}\left(\mathrm{gra} / \mathrm{cm}^{3}\right) \\
\mathrm{AOG} 1978 \\
\end{array}$ & $\begin{array}{c}\text { Organic } \\
\text { Carbon }\end{array}$ & clay & silt & sand & $\begin{array}{l}\text { Thermal conduct. } \\
\text { millifal/sececm. }\end{array}$ \\
\hline $\begin{array}{l}\text { Base } \\
\text { Station }\end{array}$ & 3.4 & 10.5 & 7.6 & 1.05 & $\begin{array}{l}1,44,1,26 \\
(2 \text { measurements) }\end{array}$ & 3.2 & 2.5 & 23.3 & 74.2 & $\begin{array}{l}2.04,1.97 \\
(2 \text { measurements) }\end{array}$ \\
\hline $\begin{array}{r}5 \\
11 \\
21\end{array}$ & $\begin{array}{l}2.3 \\
1.9 \\
2.6\end{array}$ & $\begin{array}{l}3.8 \\
3.0 \\
4.0\end{array}$ & $\begin{array}{r}12.9 \\
33.7 \\
8.3\end{array}$ & $\begin{array}{l}1.29 \\
1.23 \\
1.21\end{array}$ & $\begin{array}{l}1.67 \\
1.62 \\
1.27\end{array}$ & $\begin{array}{l}0.3 \\
4.0 \\
0.8\end{array}$ & $\begin{array}{l}3.5 \\
6.6 \\
7.5\end{array}$ & $\begin{array}{l}14.9 \\
22.4 \\
27.5\end{array}$ & $\begin{array}{l}81.6 \\
71.0 \\
65.0\end{array}$ & $\begin{array}{l}2.25 \\
2.91 \\
1.51\end{array}$ \\
\hline
\end{tabular}

Wote: 1977 soll samples taken at depths between $40-50 \mathrm{~cm}$

1978 soll samples and thermal conductivity data at a depth of $33 \mathrm{~cm}$ for Base station, 5 and 11, and at a depth of $25 \mathrm{~cm}$ for 21 .

TABLE 4: Thermal Conductivity and Diffusivity, Iong Valley August 1978

\begin{tabular}{|c|c|c|c|c|c|}
\hline STATIOS & DEPPYH (cm) & $\begin{array}{l}\text { THERMAL CONDUCTIVITY (Measured) } \\
\text { millical } / \mathrm{sec}^{\circ} \mathrm{cm} \cdot{ }^{\circ} \mathrm{C}\end{array}$ & $\rho c^{2}$ & $\begin{array}{l}\text { THBapal } \\
\text {-Measured } \\
\end{array}$ & $\begin{array}{l}(\alpha)\left(\mathrm{cm}^{2} / \mathrm{sec}\right) \\
\text { Computed } \mathrm{z}=50 \mathrm{~cm}^{2}\end{array}$ \\
\hline $\begin{array}{l}\text { Base } \\
\text { Station }\end{array}$ & 33 & 2.04 & 0.412 & 0.005 & 0.0046 \\
\hline 5 & 33 & 2.25 & 0.412 & 0.006 & 0.0055 \\
\hline 11 & 33 & 2.91 & 0.412 & 0.007 & 0.0063 \\
\hline 21 & 25 & 1.51 & 0.412 & 0.004 & 0.0041 \\
\hline
\end{tabular}

${ }^{1}$ from Ingersol et al (1954) Appendix A, for quartz sand, 8.38 molsture

${ }^{2}$ computed from phase $1 \mathrm{lag}$ of diurnal wave at a depth of $25 \mathrm{~cm}$ for station 21 and $50 \mathrm{~cm}$ the other stations. Diurnal temperature data included in Appendix B, 
Measuring thermal diffusivity, $\propto$, in this way, i.e., measuring the thermal conductivity in situ and obtaining the bulk density and specific heat from the literature, appears at this time to be the optimum method of obtaining the value of $\propto$. Though we made measurements of bulk density (Table 3 ), there appears to be too much measurement error in our data derived from a simple soil samplen. Therefore, correlations between thermal diffusivity measured in situ and measured by the phase lag method are somewhat less positive when the in situ measurements are derived from field measurements of $k$ and $\rho$ than when derived from field measurements of $k$ only. In any event, it appears that measurement of thermal diffusivity in situ is practical, and with more rigorous control in obtaining soil parameters and some modifications to the thermal conductivity probe, the required operational thermal diffusivity measurement program can be implemented.

8. Effects of Ground Water on Shallow Temperature Measurements: A Review of the Long Valley Area

Ground water flow has some effect on the temperatures recorded by shallow measurements. At Long Valley and at Upsal Hogback the water table is close to the surface and there is noticeable ground water movement. However, the shallow temperature anomalies correspond well with the anomalies at deeper "reconnaissance" depths. On the other hand, when the 30-m anomalies at Upsal Hogback and at Coso are compared with associated anomalies at depths of 1 and $2 \mathrm{~m}$, respectively, the anomaly at Upsal Hogback is less than a third the amplitude of the one at Coso and is more dispersed. We assume attenuation and spreading is due to ground water flow at Upsal Hogback since the water table at Coso is below $30 \mathrm{~m}$ and affects neither $2-\mathrm{m}$ nor 30-m measurements there.

We reviewed our work at Long Valley and that of others to obtain a better understanding of the effect of ground water movement on shallow temperature measurements.

\subsection{Location and Geology of Long Valley}

Long Valley caldera is an elliptical depression about $30 \mathrm{~km} \mathrm{E}-W$ by $17 \mathrm{~km} \mathrm{~N}-\mathrm{S}$ located at the eastern side of the Sierra Nevada range (Bailey et al 1976, see Figure 21). The eastern half of the caldera consists of a low relief valley which supports growth of sage brush and grass, where water conditions permit. The depression's western half is higher, with fault block hills and mountains of tertiary volcanics and metamorphics. Hilton Creek fault is a major fault which cuts across the central portion of the caldera on a roughly NW-SE direction and divides the western and eastern sections of the valley. A resurgent dome lies in the west central area of the caldera and is 

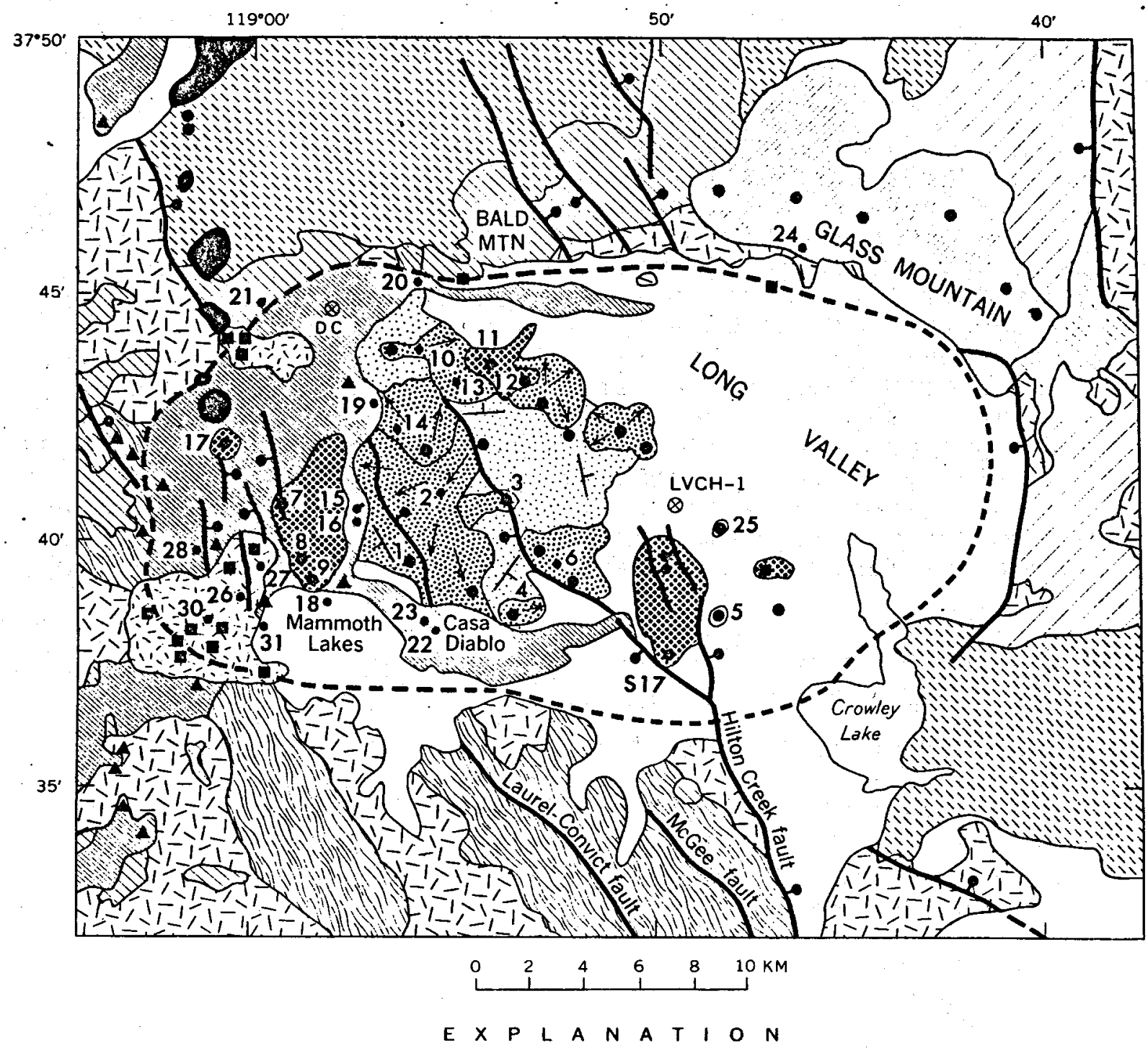

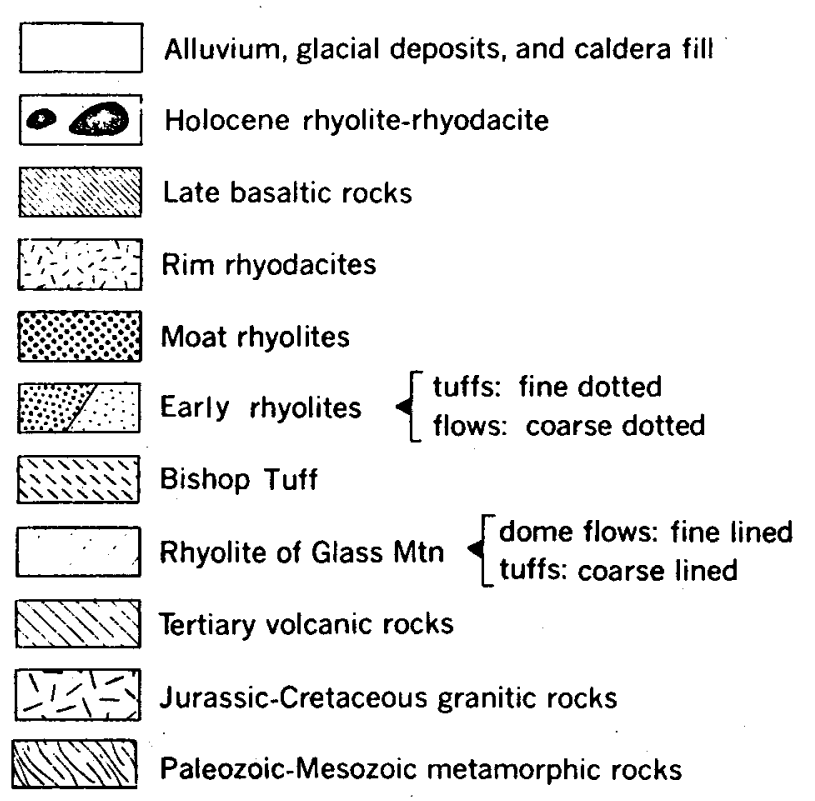

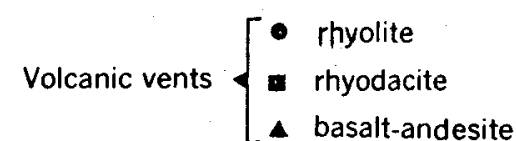

3. K-Ar sample locality

Q Drill hole

$\perp$ Direction of dip of strata

General direction of flowage of lava

e Normal fault - ball and bar on downthrown side

Outline of Long Valley caldera floor

Figure 21: Generalized geologic map of Long Valley ( after Bailey et al 1976). 
bounded by faults. According to Balley et al (1976), Long Valley caldera is one of three young enough to possibly contain residual magma in their chambers. Although surface manifestations are limited to hot springs, fumaroles, etc. (Long Valley caldera is about 0.7 million years old), Sorey (1977) recognizes three separate layers of composition in Long Valley: (1) a near-surface layer of low velocity, largely non-1ndurated sediments and volcanic rocks; (2) an underlying continuous layer of densely welded Bishop-Tuff; (3) pre-caldera granitic and metamorphic basement rocks below depths of $2.5-3.0 \mathrm{~km}$.

Thus, the general configuration of the valley is best described as a crater sloping from west to east bounded by mountains on four sides. This structure serves to explain the W-E direction of water flow in the valley (cf. Sorey, 1977).

\subsection{Ground Water Effects on Shallow Temperature Survejing}

Numerous studies have been made of shallow aquifers which affect the pattern of geothermal heat flow (cf. Birman 1969, Lovering 1963, Cartwright 1971, Lee 1977). What remains unexplained are the conditions under which shallow aquifers disturb the regional beat flow in geothermal areas.

Cartwright (1974) observed that in a non-anomalous area shallow aquifers act as heat sources or sinks, depending on the time of year. During summer, warm water recharges and cool water discharges; the pattern is reversed during winter.

The profusion of hot and cold springs in Long Valley suggest a shallow sub-system which derives its source from rainfall and run-off from the Sierra Nevada mountains, and a deeper sub-system which consists mostly of relatively coarse-grained permeable sediments. It is underlain by the Bishop Tuff which has low permeability. Sorey (1977) assumes it is this Bishop Tuff that separates the shallow sub-system from the deeper hydro-thermal system; the interconnection is made through high angle faults in which hot water flows upward. Rinehart and Ross (1964) assert that most thermal centers are obviously fault controlled.

Zones of recharge occur in the upper Owens River drainage basin along the western periphery of the caldera. Discharge occurs at the surface of Hot Creek and numerous hot springs on the eastern side of the caldera (Sorey 1977). Additional recharge infiltrates on the N-E rim and flows southward. 
Depth to the water table ranges from $0.3 \mathrm{~m}$ to about $8 \mathrm{~m}$ and data from water table elevations support a general W-E flow direction of ground water (Sorey 1977). Our temperature surveys taken at 2-m depth would in some manner be affected, depending on the location of the drill site. One tangible effect is spatial drift in temperature. Our computer plots of temperature data taken from 26 holes show a trend toward the east, pointing in the direction of ground water flow. The same effect can be observed in a temperature contour map of the Upsal Hogback area in Nevada showing a trend towards the $N-E$, the direction of water flow (Olmsted 1977). Knowing the direction of ground water flow and the water table level, we can better understand the heat flow distribution in a geothermal setting.

Theoretical modeling by Domenico and Palciouskas (1973) shows that discharge areas have higher temperatures than recharge areas. Convective heat losses on the recharge side are balanced by heat gains on the discharge side. They conclude that any water table configuration which tends to shift toward the valley bottom or the topographic high will have a pronounced effect on the temperature distribution. This observation is borne out in shallow temperature measurements at Long Valley, where there is a lower temperature on the western high slopes and a higher temperature in the eastern valley. If we include the perturbations of hot springs and pools the picture becomes more complex. Factors such as permeability, structure and reservoir configuration must be considered.

Lee (1977) states that ground water movement may affect temperature measurements by changing the thermal diffusivity and conductivity of soils. Our work at Long valley showed these perturbations were practically negligible due to the strength of the anomaly. However, thermal diffusivity values in rock are greatly affected by weather, porosity and moisture and moisture content (Lovering and Goode 1963). Moisture content depends not only on rainfall and humidity but also on subsurface ground water. knowing the pattern and distribution of ground water flow allows correlation with local soil thermal diffusivity values.

Structural features, such as faults or fissures also influence to some degree the heat flow distribution in a geothermal area. It is believed the hot springs and pools in Long Valley lie along high angle faults which serve as conduits for hot water rising to the surface (Bailey 1976). During the field program at Long Valley, two traverses were made across a marshy area in the north central section of the caldera adjacent to the alkali lakes (Figure 22). On two roughly parallel N-s traverses a total of 21 holes were drilled with about 150 meters 
between them. The range of temperatures obtained from hole-to-hole varied as much as $15^{\circ} \mathrm{C}$. Data gathered during 2 days revealed no distinct pattern. The area had abundant hot springs and cold stream flows.

Bailey (1977) pointed out that in the same area hot springs lined up in a NW-SE direction along faults. It is concelvable that by drilling along these faults high temperatures such as in holes $49\left(45.17^{\circ} \mathrm{C}\right)$ and $36\left(28.03^{\circ} \mathrm{C}\right)$ would be encountered. In Figure 23 we have plotted profiles of temperatures vs distance along the two survey lines $\mathrm{AA}^{\prime}$ and $\mathrm{BB}^{\prime}$. A match between peaks of points 47 and 36 suggests a fault connecting the two points of the different traverses in a NW direction. As verified by Rinehart and Ross (1964), most faults lie on a N-NW axis in Long Valley. Other observations reveal numerous small alkali lakes as an indication of a near-surface water table (Sorey 1977).

Aerial photographs also clarify and supplement ground observations. On color photos of Long Valley taken on a scale of $1: 20,000$, we have identified distinct color differences separating high and low temperature areas on the surface. On Figures 22 , points $45,49,51$ and 53 on traverse $A^{\prime}$ ' are located on darker color saturated areas which correspond to areas of more intense geothermal activity. Points such as 44,46 and 52 are in dry, bleached areas as verified by ground surveys. The bleached areas generally consist of calcareous deposits left by geothermal brines. They also indicate areas of past geothermal activity.

One must be careful with such observations. At Long Valley, owing to the complexity of the hydrothermal system, temperatures are unpredictable. In addition to temperature measurements, temperature gradients also provide a means of ground water analysis. Birman (1969) observed that when measured temperatures fell below the predicted temperatures (arrived at by extrapolating gradients) there was clear indication of cooling by shallow ground water recharge. Regions in the central portion of the caldera, with an abundance of hot springs and high gradients, on the other hand, are characteristic of discharge areas. This suggests that when geothermal gradients are uniform and vary in a predictable fashion, there is little ground water disturbance.

Many questions remain unanswered. Among these is the hazard of extrapolating temperature gradients at depth from shallow temperature data, particularly in areas affected by shallow ground water flow (Lovering and Goode, 1963; Lachenbruch et al, 1976). Olmsted's work in Nevada (1977) and our studies at Long Valley (LeSchack et al 1977) show that where anomalies are strong, risks can be minimized and good correlation obtained between shallow and deeper data. 

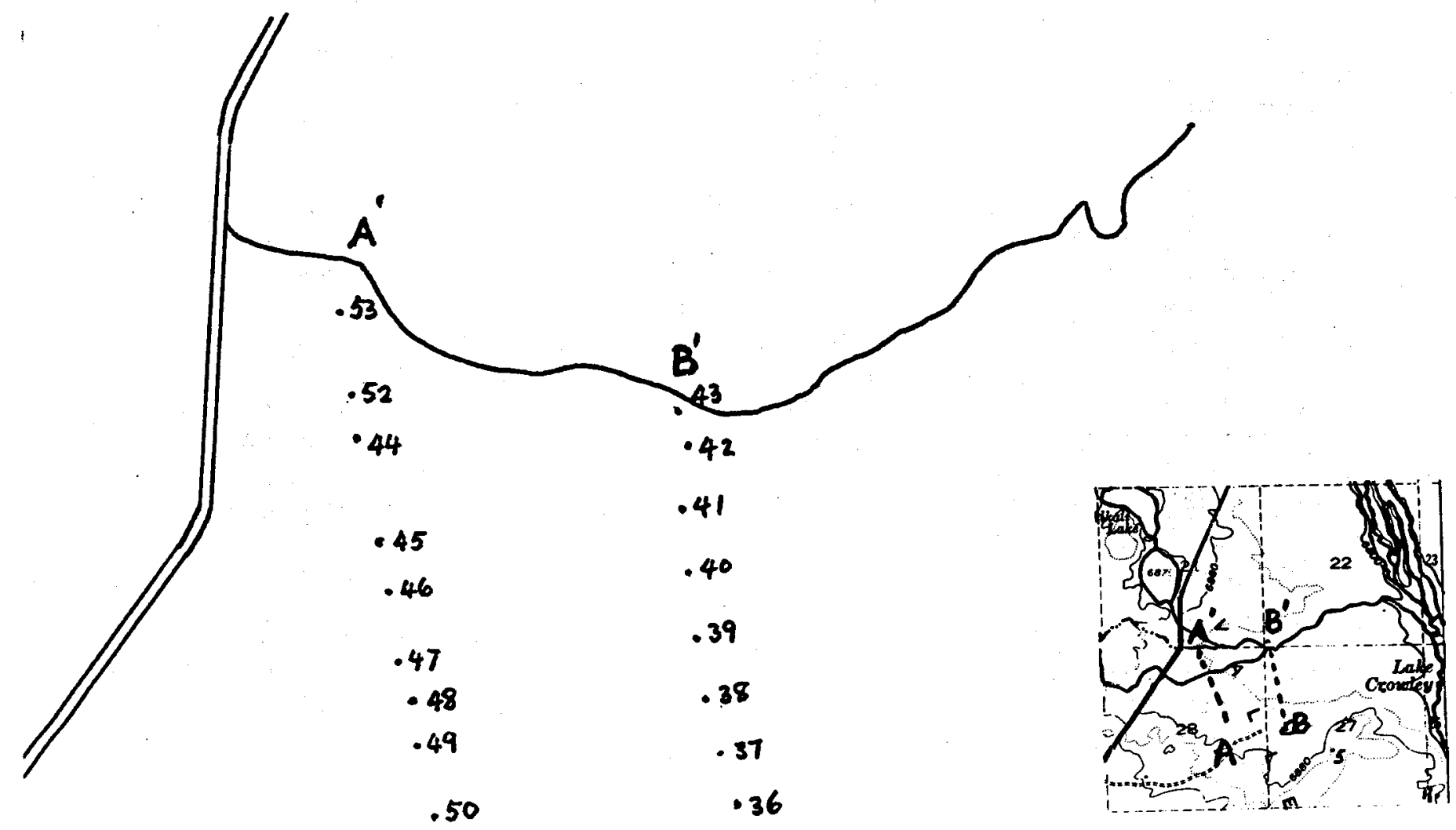

From U.S.G.S. $15^{\prime}$ Map 1953

Mt. Morrison Quadrangle

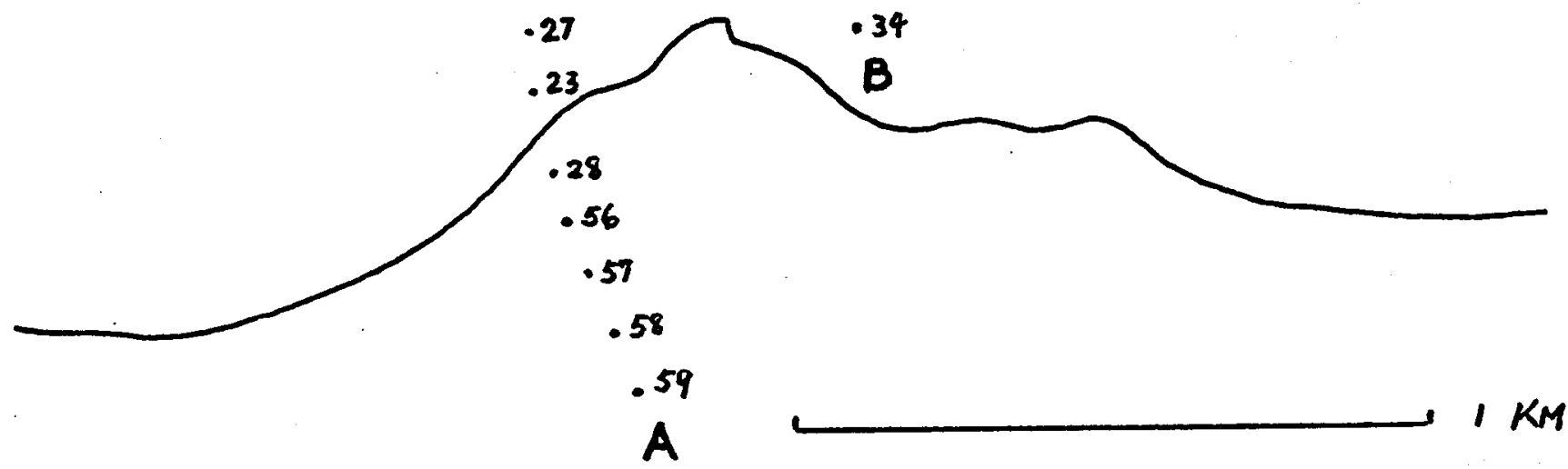

Figure 22: Location of holes drilled in marsh area along traverses $A^{\prime}$ and $B^{\prime}$ (see inset map). 

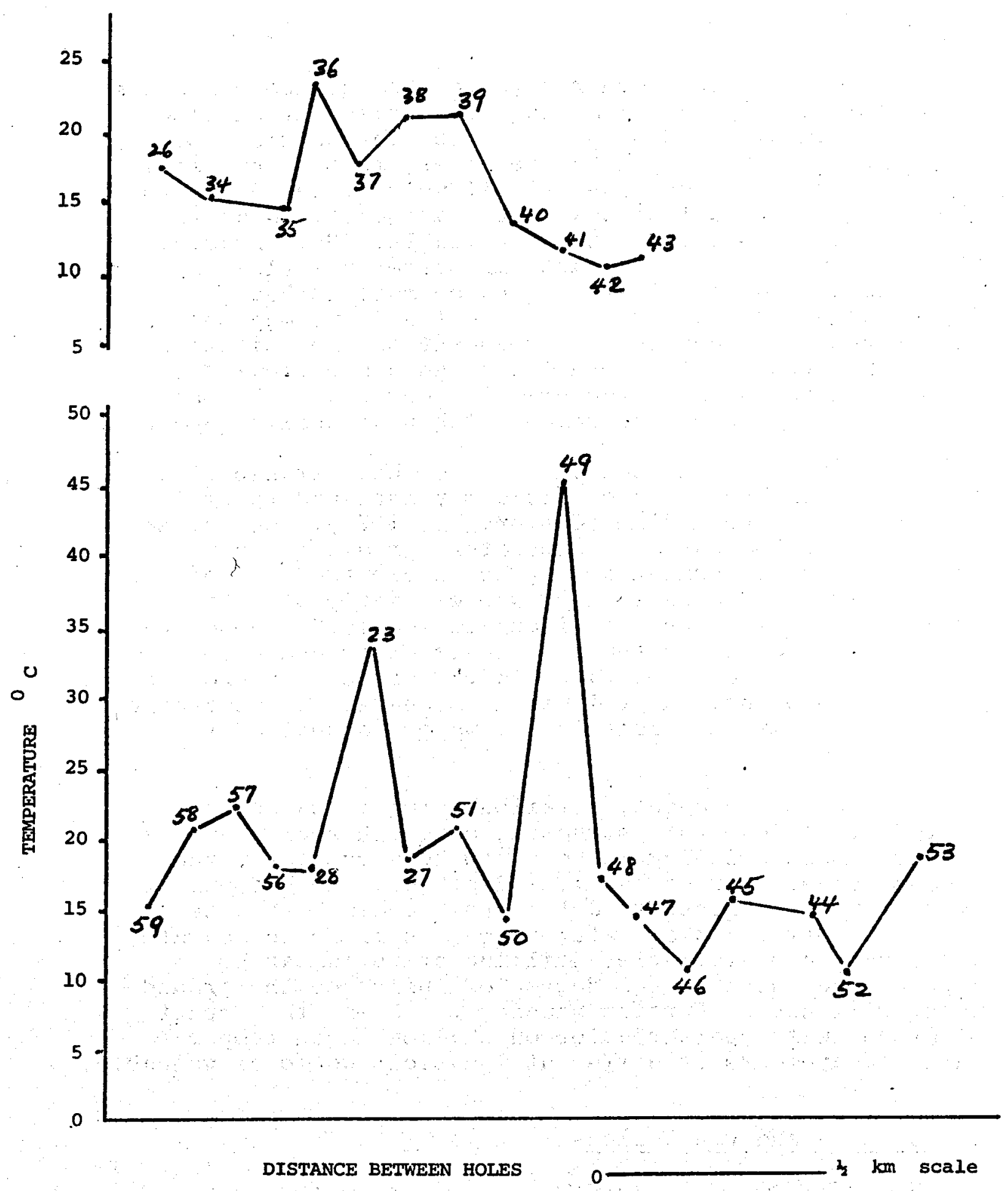

Figure 23: Temperature profiles of survey lines AA (bottom) and $\mathrm{BB}^{\prime}$ ( $\left.t o p\right)$. Note the peak temperatures for sites 36 and 49 . 
Many factors contribute to the erroneous results which plague temperature measurements taken at shallow depth. Conditions such as variations in the micro-climate, precipitation, vegetative cover, topography, soil moisture, soil or rock thermal diffusivity and depth to the water table must be taken into account, and appropriate corrections made when applicable. Paraphrasing the observations of Poley and Van Steveninck (1970) that "heat conductivity of a rock or soil is heavily dependent on the latter's water content," we may conclude that since water content is dependent on precipitation rates and ground water conditions, adequate knowledge of both is essential to accurately correct geothermal anomaly temperature measurements taken at shallow depth.

Furthermore, the quantity of heat transported depends on the velocity of fluid movement and thermal properties of the medium (Cartwright, 1971). Schneider (1964) observed that low temperature gradients where water is less mineralized "may be attributed to free and relatively rapid circulation, whereas water of poor quality probably does not circulate freely." These observations underscore the importance of ground water studies in shallow temperature work, since they provide information on heat distribution, recharge and discharge areas, temperature gradients and water content of the soil or rock.

At the present, detailed information on the hydrothermal reservoir structure of geothermal areas is scanty. Deep drilling is bound to be very costly and inconclusive. For our shallow depth measurement purposes, it is adequate to determine the depth to water table and direction of water flow. In areas where water table data are available, drilling criteria can be applied according to the degree of influence the ground water will have. Further studies to assess the impact of ground water perturbation on shallow depth temperature measurements at different locations would be valuable.

\section{Summary and Conclusions}

In LeSchack et $a i$ (1977), the first technical report under this contract, we concluded that the shallow temperature survey method should be one of the first geophysical surveys initiated at a geothermal prospect. It is a simple, effective guide to development and the expenditure of financial resources for embarking on a detailed exploration program. 
In the present work, we have studied in much greater detall the previously examined geothermal sites at Long Valley and Coso. We have evaluated techniques for correcting the $2-m$ temperature data. We conclude that our earlier findings are upheld by the more recent work.

Using a preliminary model and analysis of the Coso data, we showed the importance of measuring sotl thermal diffusivity data at each temperature probe site. We examined Olmsted's (1977) $1-m$ temperature data at Upsal Hogback, Nevada. By analogy with our own data we suggested corrections for soll thermal diffusivity to his data set. When applied, his shallow temperature measurements more nearly targeted an anomaly found at $30 \mathrm{~m}$ than did his uncorrected data.

We compared our corrected 2-m temperature anomaly at Coso with a low altitude aeromagnetic anomaly and an anomaly outlined by electrical resistivity methods obtained Independentiy by the University of Uath; they coincide well.

We made preliminary tests with a simple thermal conductivity probe demonstrating the feasibility of measuring soil thermal diffusivity at the time the 2-m temperatures are recorded. This opens the way for operational shallow temperature surveys in areas which do not have, as at Coso, a simple set of surface conditions.

Finally, we conclude that making useful shallow temperature measurements where there is a modest amount of ground water flow needn't be a hopeless task. Though it often complicates the interpretation of the results, it does not invalidate application of the technique.

In short, with another year of field study and analysis behind us, we believe the conclusions drawn in our previous report are firmly substantiated, Shallow temperature surveying, if conducted properly, is an inexpensive and rapid reconnaissance tool for geothermal exploration. 


\section{Acknowledgement}

We wish to acknowledge the many persons who assisted us in gathering field data and who provided guldance in our research.

At the U.S. Naval Weapons Center, the site of the Coso KGRA, we could continualiy count on the assistance and good will of Dr. Carl Austin, Carl Halsey, Charles Rodgers and Dr. James Whelan. These gentleman assisted in many ways in expediting and supporting our efforts at the Naval Weapons Center.

Dr. Roy A. Bailey, USGS, Reston, Virginia, gave us much guidance at the Long Valley site where he has conducted extensive research. We also wish to thank Dr. Robert Andrews of the Earth Physics Program of the Office of Naval Research and Larry Ball of the Division of Geothermal Energy, Department of Energy, for criticaliy reviewing our manuscripts. 


\section{References}

Bailey, R,A, 1977, perisonal communication, USGS, Reston, Va.

Bailey, R,A, Dalrymple, G.B, , and Lanphere, M.A., 1976, Volcanism, Structure and Geochronology of Long Valley Caldera, Mono County, Caltfornia, J, Geophys, Res,, V81, No, 5, pp725-744,

Birman, J, 1969, Geothermal Exploration for Ground Water, GSA Builetin V, 80, pp617-630.

Cartwright, $K_{,}, 1971$, Redistribution of Geothermal Heat by a Shallow Aquifer, GSA Bulletın V. 82, N, 11, pp3197-3200.

Cartwright, K., 1974, So11 Temperature and Ground Water Flow, Water Resources Research, V. 10, N 4 pp847-855.

Domenico, P,A, and Palclouskas, V.V., 1973, Theoretical Analysis of Forced Convective Heat Transfer in Regional Ground Water Flow, GSA Bulletin, V. 84, N, 12, pp3803-3814.

Fox, R.C., 1978a, Dipole-Dipole Resistivity Suryey of a Portion of the Coso Hot Springs KGRA, Inyo County, California, Univ. of Utah Research Inst, Earth Sc1, Lab., Salt Lake City, under Contract EY-76-S-07-1601 for Dept. of Energy.

Fox, R.C., 1978b, Low Altitude Aeromagnetic Survey of a Portion of the Coso Hot Springs KGRA, Inyo County, California, Univ of Utah Research Inst. Earth Sci. Lab., Salt Lake City, under Contract No, EY-76-S-07-1601 for Dept. of Energy.

Fox, R.C. 1978c, Personal Communication, Univ. of Utah Research Inst., Earth Sci. Lab., Salt Lake City.

Hooper, F.C. and Lepper, F.R., 1950, Transient Heat Flow Apparatus for the Determination of Thermal Conductivities, Trans. Am. Soc. Heating Ventilating Engrs. V56, pp309-322.

Hulen, J.B., 1978, Geology and Alteration of the Coso Geothermal Area, Inyo County, California, Univ. of Utah Research Inst. Earth Sci. Lab., Salt Lake City, under Contract EG-78-C-07-1701 for Dept. of Energy.

Ingersoll, L.R., Zobel, O.J., and Ingersoll, A.C., 1954, Heat Conduction with Engineertng, Geological and other Applications, Univ, of Wisconsin Press, Madison

Lachenbruch, A.H, Sorey, M.L., Lewis, R.E., and Sass, J.H. 1976, The Near-Surface Hydrothermal Regime of Long Valley Caldera, J, of Geophs. Res., V 81, No 5, pp 763-768, 
Lee, Tien-Chang, 1977, On Shallow-Hole Temperature Measurements-A Test Study in the Salton Sea Geothermal Field, Geophysics, V 42 No 3 , pp 572-583.

LeSchack, L.A., Lewis, J.E., Chang, D.C., 1977, Rapid Reconnaissance of Geothermal Prospects Using Shallow Temperature Surveys. Development and Resources Transportation Co. (now LeSchack Associates, Ltd.) Silver Spring, Md. 20902, Semi-Annual Tech. Rept. under Contract EG-77-C01-4021 for the Dept. of Energy.

Lettau, H.H., 1969, Note on Aerodynamic Roughness--Parameter Estimation on the Basis of Roughness--Element Description, J. Applied Meteorology, V8, No 5, pp 828-832.

Lovering, T.S. and Goode, H.D., 1963, Measuring Geothermal Gradients in Drill Holes Less than 60 Feet Deep East Tintic District, Utah, U.S. Geol. Survey Bul. 1172.

O!Hara, N.W., 1977, Personal Communication, Florida Institute of Technology, Melbourne, Florida.

Olmsted, F.H., 1977, Use of Temperature Surveys at a Depth of 1 Meter in Geothermal Exploration in Nevada, USGS Professional Paper 1044-B.

Olmsted, F.H., 1978, Personal Communication, USGS, Menlo Park, Calif.

Poley, J. Ph. and Van Steveninck, J., 1970, Geothermal Prospecting--Delineation of Shallow Salt Domes and Surface Faults by Temperature Measurements at a Depth of Approximately 2 Meters, Geophs. Prospecting, V 18, pp 666700 .

Rinehart, C.D. and Ross, D.C., 1964, Geology and Mineral Deposits of the Mount Morrison Quadrangle, Sierra Nevada, California, USGS, Prof. Paper 385.

Schneider, R., 1964, Relation of Temperature Distribution to Ground Water Movement in Carbonate Rocks of Central Israel, GSA Bulletin V 75 pp 209-215.

Sorey, M.L., 1977, The Hydrothermal System of Long Valley USGS Bulletin 1044A.

Van Wijk, W.R. (Ed.), 1966, The Physics of Plant Environment, North Holland Publishing Co., 2nd Ed, Amsterdam 


\section{APPENDIX A: Map Contouring by SYMAP}

When contouring our data for presentation, especially when comparing our anomalies with those generated by other researchers, we tried to avold blas. Our data were contoured by the SYMAP computer program (version 5.20) designed by the Laboratory for Computer Graphics and Spatial Analysis, Graduate School of Design, Harvard University, Cambridge, Massachusetts, 02138. The program takes the maximum and minimum points in a data set and obtains their difference. The difference value is divided by five, forming five equi-dimensional cells. The numerical boundary between the lowest and next lowest cell becomes the value of the lowest contour. The next highest contour is the boundary between the second lowest and the middle cell, etc., for a total of four contour lines. Contour values and intervals are derived when the data set is specified. Different typographic characters are used to "fill in" the space between contours. In each field of characters numbers from 1 to 5 correspond to geographic locations of the data points being contoured. A figure " 1 " represents the location of a given point whose range falls within the confines of the lowest cell. A figure "5" represents the location of a data point in the highest cell. 
APRENDIX B

Temperature Measurements $\left({ }^{\circ} \mathrm{C}\right)$ at Long Valley on 11-12 August 1978

Base Station

Depth (m)

\begin{tabular}{lllllll} 
Time & 0.10 & 0.25 & 0.50 & 1.0 & 1.5 & 2.0 \\
\hline & & & & & & \\
0819 & 13.92 & 16.86 & 17.13 & 15.07 & 13.19 & 11.54 \\
1420 & 23.59 & 17.18 & 17.01 & 15.09 & 13.21 & 11.59 \\
2035 & 20.45 & 19.00 & 16.91 & 15.08 & 13.25 & 11.60 \\
0230 & 15.60 & 18.35 & 17.01 & 15.09 & 13.27 & 11.64 \\
0935 & 14.10 & 16.75 & 17.01 & 15.07 & 13.27 & 11.65
\end{tabular}

Station 5

Depth (m)

\begin{tabular}{lllllll} 
Time & 0.10 & 0.25 & 0.50 & 1.0 & 1.5 & 2.0 \\
\hline 0724 & 15.61 & 20.17 & 20.42 & 18.98 & 17.80 & 16.03 \\
1334 & 27.20 & 19.90 & 20.21 & 18.96 & 17.80 & 16.04 \\
1915 & 24.60 & 22.68 & 20.19 & 18.98 & 17.80 & 16.07 \\
0140 & 17.34 & 21.67 & 20.38 & 18.93 & 17.80 & 16.08 \\
0749 & 13.35 & 19.40 & 20.40 & 18.93 & 17.81 & 16.11 \\
0832 & 13.80 & 19.14 & 20.34 & 18.92 & 17.80 & 16.11
\end{tabular}

Station 11

Depth (m)

\begin{tabular}{lllllll} 
Time & 0.10 & 0.25 & 0.50 & 1.0 & 1.5 & 2.0 \\
\hline 0740 & 18.35 & 20.46 & 20.28 & 18.72 & 17.21 & 15.50 \\
1349 & 23.39 & 20.00 & 20.03 & 18.71 & 17.21 & 15.49 \\
1937 & 24.60 & 22.01 & 19.98 & 18.70 & 17.21 & 15.53 \\
0155 & 19.95 & 21.41 & 20.20 & 18.68 & 17.21 & 15.55 \\
0804 & 16.72 & 19.79 & 20.11 & 18.67 & 17.22 & 15.55 \\
\hline
\end{tabular}

Station 21

Depth (m)

\begin{tabular}{lllllll} 
Time & 0.10 & 0.25 & 0.50 & 1.0 & 1.5 & 2.0 \\
\hline 0712 & 18.66 & 20.93 & 20.69 & 19.16 & 17.59 & 16.40 \\
1323 & 22.75 & 20.38 & 20.56 & 19.12 & 17.60 & 16.40 \\
1855 & 25.20 & 21.93 & 20.45 & 19.11 & 17.61 & 16.42 \\
0125 & 20.33 & 21.86 & 20.61 & 19.10 & 17.62 & 16.45 \\
0739 & 16.93 & 20.42 & 20.65 & 19.09 & 17.65 & 16.48 \\
0852 & 16.74 & 20.15 & 20.60 & 19.07 & 17.65 & 16.48
\end{tabular}

